\title{
Article
}

\section{Transaminase Catalysis for Enantiopure Saturated Heterocycles as Potential Drug Scaffolds}

\author{
Ágnes Malta-Lakó ${ }^{1,2, *(\mathbb{D})}$, Fangyi Zhang ${ }^{1}$, Ricardo Mendonça ${ }^{2} \mathbb{D}$ and László Poppe 1,3,4,*D $^{\mathbb{D}}$ \\ 1 Department of Organic Chemistry and Technology, Budapest University of Technology and Economics, \\ Múegyetem rkp. 3, H-1111 Budapest, Hungary; zhang.fangyi@edu.bme.hu \\ 2 Hovione Farmaciência, S.A., Campus do Lumiar, Edifício R, Estrada do Paço do Lumiar, \\ P-1649-038 Lisboa, Portugal; rmendonca@hovione.com \\ 3 SynBiocat Ltd., Szilasliget u 3, H-1172 Budapest, Hungary \\ 4 Biocatalysis and Biotransformation Research Center, Faculty of Chemistry and Chemical Engineering, \\ Babeş-Bolyai University of Cluj-Napoca, Arany János Str. 11, RO-400028 Cluj-Napoca, Romania \\ * Correspondence: lako.agnes@edu.bme.hu (Á.M.-L.); poppe.laszlo@vbk.bme.hu (L.P.)
}

Citation: Malta-Lakó, Á.; Zhang, F.;

Mendonça, R.; Poppe, L.

Transaminase Catalysis for

Enantiopure Saturated Heterocycles as Potential Drug Scaffolds. Catalysts 2021, 11, 1501. https://doi.org/ 10.3390/catal11121501

Academic Editor:

Roberto Fernandez-Lafuente

Received: 12 November 2021

Accepted: 3 December 2021

Published: 10 December 2021

Publisher's Note: MDPI stays neutral with regard to jurisdictional claims in published maps and institutional affiliations.

Copyright: $\odot 2021$ by the authors. Licensee MDPI, Basel, Switzerland. This article is an open access article distributed under the terms and conditions of the Creative Commons Attribution (CC BY) license (https:// creativecommons.org/licenses/by/ $4.0 /)$.

\begin{abstract}
As efforts in rational drug design are driving the pharmaceutical industry towards more complex molecules, the synthesis and production of these new drugs can benefit from new reaction routes. In addition to the introduction of new centers of asymmetry, complexity can be also increased by ring saturation, which also provides improved developability measures. Therefore, in this report, our aim was to develop transaminase (TA)-catalyzed asymmetric synthesis of a new group of potential chiral drug scaffolds comprising a saturated amine heterocycle backbone and an asymmetric primary amine sidechain (55a-g). We screened the Codex ${ }^{\circledR}$ Amine Transaminase Kit of 24 transaminases with the morpholine containing ketone 57a, resulting in one $(R)$-selective TA and three $(S)$-selective TAs operating at $100 \mathrm{mM}$ substrate concentration and $25 v / v \%$ isopropylamine (IPA) content. The optimized reaction conditions were than applied for asymmetric transamination of further six ketones $(\mathbf{5 7 b}-\mathrm{g})$ containing various amine heterocycles, in which a strong effect of the substitution pattern of the $\gamma$-position relative to the substituted $N$-atom could be observed. Mediated by the most enantiotope selective $(S)$-TAs in scaled-up process, the $(S)$-amines $[(S)$-55a-g] were isolated with moderate-to-excellent yields (47-94\%) in enantiopure form (>99\% ee).
\end{abstract}

Keywords: transaminase; biocatalysis; asymmetric reaction; chiral amine; drug scaffold; saturated heterocycle; stable $\mathrm{N}$-centered stereogenic element

\section{Introduction}

With the rise of rational drug design, Lipinski's rule of five (RO5) quickly became standard practice to determine bioavailability for oral drug candidates based on physicochemical properties [1]. However, new active pharmaceutical ingredients (APIs) are more and more complex; therefore, the RO5 needs to be complemented by further structural feature analysis [2]. According to the analysis of Ritchie et al. on the effect of aromatic ring count on drug developability, the increasing number of widely used aromatic rings leads to decreased druglikeness [3]. Consequently, a diversity-oriented synthesis approach is necessary to widen the pool of biologically interesting small molecules [4]. Aldeghi and coworkers defined rings without $\mathrm{sp}^{3}$ hybridized carbon atoms as $2 \mathrm{D}$ rings that were planar or flat scaffolds, but 3D rings must contain at least one $\mathrm{sp}^{3}$ hybridized carbon atom, rendering the ring nonplanar [5]. Looking at the most frequently used 2D and 3D fragments in marketed APIs, although the phenyl ring (1) is in the number one position, three saturated heterocycles (morpholine (2), piperidine (3) and piperazine (4)) take the following top positions (Figure 1). These 3D fragments-by escaping from Flatland-allow the preparation of more complex and less rigid molecules by introducing asymmetric centers without significantly increasing molecular weight [6]. Furthermore, increasing ring saturation 
count has proven to be beneficial regarding developability measures such as solubility, lipophilicity, protein binding, P450 inhibition and hERG (the human ether-à-go-go-related gene) binding [7].<smiles>c1ccccc1</smiles>

1

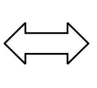<smiles>[CH]1C[CH]NC1</smiles>

3<smiles>C1CCC(C2CCCCC2)CC1</smiles>

4

Figure 1. The most abundant $2 \mathrm{D}$ and $3 \mathrm{D}$ rings in APIs.

In 2014, 59\% of the small-molecule drugs approved by the U.S. Food and Drug Administration (FDA) were reported to contain a nitrogen heterocycle [8]. The piperidine scaffold has been incorporated into a great array of drugs with varying biological effects, including analgesics, antipsychotics and antihistamines [9]. Piperazine, the six-membered, two-nitrogen-containing heterocycle, can be used as a flexible linker scaffold that provides two heteroatoms for further functionalization. Therefore, this building block can be found in various known drugs with antidepressant, anticancer, anthelmintic, antibacterial, antifungal, antimycobacterial, antimalarial, anticonvulsant, etc. effects [10]. Furthermore, a large number of APIs have also been reported with morpholine scaffolds with different contributions to molecular activity such as enhanced binding affinity, potency or selectivity, metabolic and pharmacokinetic benefits or good druglike properties [11].

As in vitro drug discovery efforts are driving the field towards the preparation of more complex molecules, enantioselective synthesis is gaining more and more importance. Thus, biocatalysis employing highly (stereo)selective enzymes is becoming more sought after [12]. Since the development of the industrial-scale chemoenzymatic synthesis of sitagliptin, which employed an engineered TA [13], TAs have been intensely studied [14]. These enzymes catalyze the enantiotope selective synthesis of chiral amines from prochiral ketones [15]; therefore, it is no surprise that efforts have been made to use TAs to access chiral heterocycles. Many API syntheses have indicated that chemoenzymatic solutions can provide shorter and more efficient synthesis as compared to "traditional" chemical syntheses when developing a new manufacturing route (Figure 2).
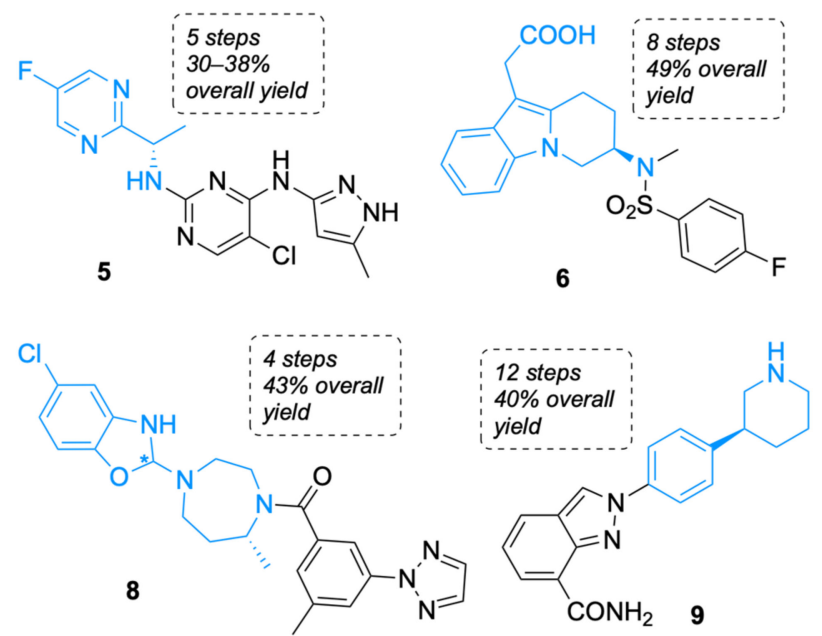

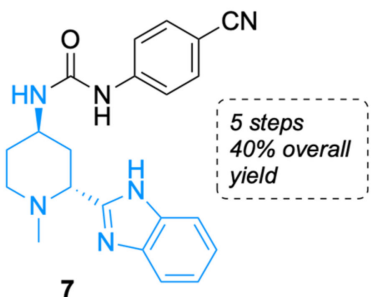

7

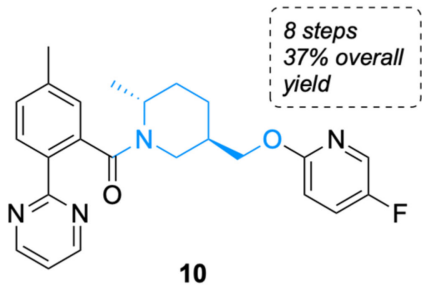

Figure 2. APIs produced by chemoenzymatic manufacturing processes. The portion of the API's skeleton colored in blue was involved in the biocatalytic step. * The asterisk in structures indicates center of asymmetry here and in any further figures. 
Researchers at AstraZeneca realized, as an efficient way for the manufacture of the chiral amine building block in the Janus kinase (JAK) inhibitor 5, asymmetric synthesis starting from the corresponding prochiral ketone using a TA from Vibrio fluvialis and (S)-methylbenzylamine (S-MBA) as amine donor $[16,17]$. To improve the synthesis of $\mathrm{CRTH}_{2}$ (chemoattractant receptor homologue expressed on $\mathrm{Th}_{2}$ cells) antagonist 6, Merck's chemists switched from using the chiral pool to construct the asymmetric center to a process applying a commercially available TA and isopropylamine (IPA) as the amine donor, leading to significant enhancement in overall yield and productivity [18]. For the synthesis of smoothened receptor (Smo) inhibitor 7, Pfizer's researchers implemented a transamination occurring parallel with a dynamic kinetic resolution (DKR) of the starting racemic ketone, establishing two stereogenic centers in a single step [19]. Thus, employing a commercially available TA with IPA as the amine donor resulted in a >10:1 diastereomeric ratio $(d r)$ and $>99 \%$ enantiomeric excess (ee). Developing the enantioselective synthesis of dual orexin inhibitor suvorexant (8) at Merck, a tandem transamination/ring annulation strategy was envisioned to synthesize the chiral seven-membered ring [20]. For the enzymatic step, the sitagliptin TA [13] was used in combination with IPA as the donor. A combination of the previous two strategies could be applied for the synthesis of poly(ADP-ribose)polymerase inhibitor niraparib (9). One enantiomer of the racemic open-chain aldehyde, upon transamination, would form a lactam while the unreacted aldehyde underwent racemization; therefore, in the DKR process, only the desired enantiomer would form [21]. A commercially available TA with IPA readily catalyzed this transformation. The synthesis of the chiral intermediate in Merck's dual orexin receptor antagonist $\mathbf{1 0}$ also relied on lactamization to piperidone [22]; furthermore, the researchers explored the application of both alanine [22] and IPA [23,24] as amine donors with the commercially available TA.

In addition to the researchers involved in the development of these manufacturing process examples, numerous research groups have been working on TA-catalyzed synthesis of pharmacologically relevant scaffolds. As discussed previously, 2D heterocycles containing only $\mathrm{sp}^{2}$ hybridized carbons cannot provide asymmetric centers; therefore, asymmetry can be introduced only in their substituents via carbonyl groups that are convertible by TAs into the respective chiral amine derivatives (Figure 3).

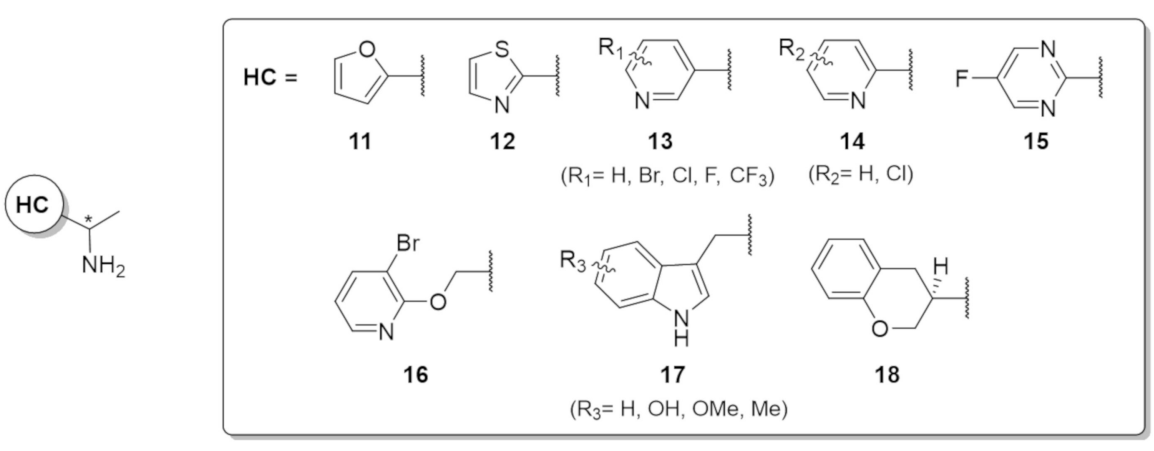

Figure 3. Heterocycles bearing asymmetric side chains with amine function by TA-catalysis.

The most frequent example is the transamination of the acetyl group: 2-acetylfuran (11) [25], 2-acetylthiazole (12) [26], substituted 1-, 2- or 3-acetylpyridines (13, 14) [26-33] and 2-acetyl-pyrimidine $(\mathbf{1 5})[16,17]$ have been reported to undergo transamination with a great variety of TAs. In addition, more specific drug-precursor molecules have been also reported, e.g., oxypropanone-substituted 16 [34] and 3-acetone-substituted 17 [35]. In contrast, if the acetyl group is connected to a $3 \mathrm{D}$ ring through an $\mathrm{sp}^{3}$ hybridized carbon atom, the starting molecule is already chiral. Thus, the transamination of the enantiopure (S)-ketone forming by ene-reductase from the corresponding $\alpha, \beta$-unsaturated ketone leads to either enantiopure diastereomer of amine $\mathbf{1 8}$ depending on the stereopreference of the applied TAs [36]. 
Cyclic ketones enable the option of desymmetrization of a carbon atom that is part of the ring (Figure 4).

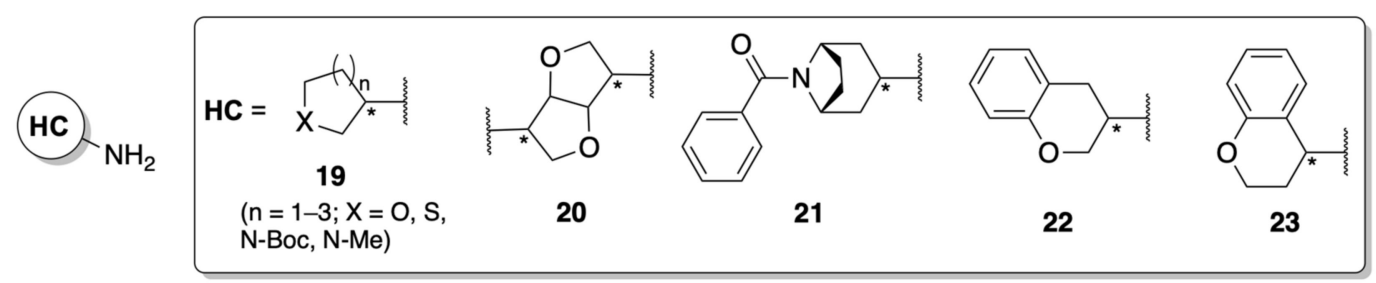

Figure 4. Amines from biocatalytic transamination of the corresponding cyclic ketones.

Five-membered heterocycles, substrates of TAs $(\mathbf{1 9}, n=1)$, can contain in $\beta$-position to the carbonyl group oxygen, sulfur, or protected nitrogen as heteroatoms [34,35]. Further examples can be found for six- [37,38] and seven-membered [39] $N$-heterocycles $(\mathbf{1 9}, n=2-3)$ as well. However, to avoid additional protection and deprotection steps, it is important to introduce the asymmetric amine function at the later stages of the API synthesis; therefore, extended ring systems are critical targets for TA-catalyzed reactions. For example, from a bicyclic substrate with two carbonyl groups-obtained by oxidation of the two hydroxyl groups of isosorbide-four stereoisomers of $\mathbf{2 0}$ can be synthesized with the appropriate TAs [40]. Furthermore, protein engineering of a TA involving rational design and directed evolution elements enabled the creation of an enzyme capable of transamination of increasingly complex molecules such as the sterically hindered $\mathbf{2 1}$ containing a bridged bicyclic ring [41]. Finally, hybrid heterocyclic ring systems containing 2D and 3D elements, such as 3- (22) and 4-chromanone (23), could also serve as substrates to multiple TAs [42].

Truppo and coworkers recognized that product inhibition of transamination can be eliminated if the forming amine product undergoes a spontaneous and irreversible reaction to form a secondary product (Figure 5).

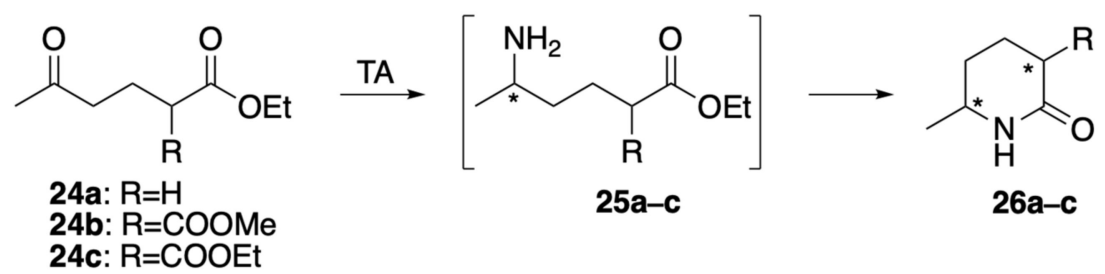

Figure 5. Transaminase-mediated synthesis of piperidone derivatives from keto esters.

For example, in the process starting from 24a, the amino ester 25a spontaneously cyclizes to the optically pure 26a lactam [43]. The cyclization displacing the reaction equilibrium allowed up to $50 \mathrm{~g} / \mathrm{L}$ substrate concentration in this process. This process was exploited for the synthesis of $\mathbf{2 5 b}$ as an intermediate to MK-6096 (10). First, in this case, alanine was used as the amine donor to further displace the equilibrium by removal of the forming pyruvate by a lactate dehydrogenase (LDH) / glucose dehydrogenase (GDH) system (first generation synthesis by three enzymes) [22]. The industrial applicability of the first-generation synthesis was successfully demonstrated on a kilogram scale starting from $4.5 \mathrm{~kg}$ of $24 \mathrm{~b}$. Later, alanine was replaced with isopropylamine as amine donor, reducing this process to a one-enzyme system (second generation synthesis) [23]. While with the three-enzyme system alkaline workup was necessary for lactamization, the transamination of 24a at elevated $\mathrm{pH}$ led to spontaneous lactamization of 25a. Finally, third-generation synthesis combining the previous two solutions and employing the one-enzyme system at elevated $\mathrm{pH}$ enabled the transamination of $24 \mathrm{c}$ to achieve 26c [24].

Another spontaneous cyclization following transamination is the intramolecular aza-Michael reaction (IMAMR) for the preparation of 2,6-disubsituted piperidines [44] and cyclic $\beta$-enaminones (Figure 6), both key building blocks for the synthesis of valuable alkaloids [45]. 


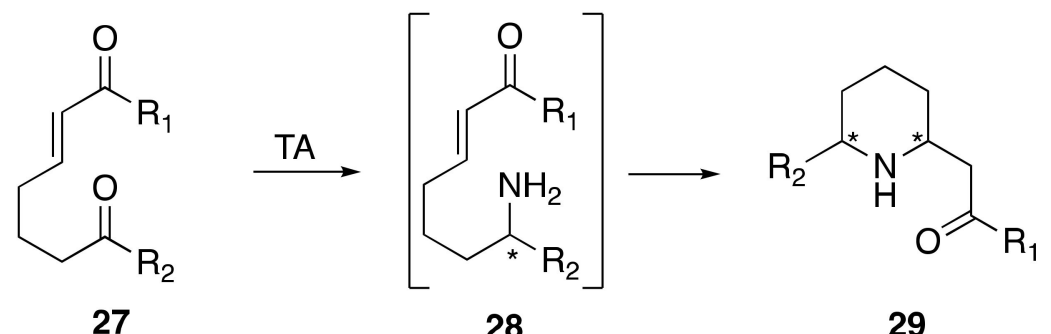

$\mathrm{R}_{1,2}=\mathrm{Alkyl}, \mathrm{Ar}$<smiles>[R5]C(=O)C#CCCCC(C)=O</smiles>

30

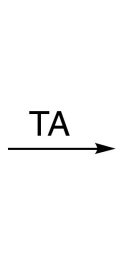

$\mathrm{R}_{3}=$ Alkyl, OAlkyl, $\mathrm{Ar}$<smiles>[R5]C(=O)/C=C1\CCC[C@H](CC)N1</smiles>

31
32

Figure 6. Tandem TA/intramolecular aza-Michael reaction for 2,6-disubstituted piperidines.

Starting from $\mathbf{2 7}$, the first center of asymmetry is created in $\mathbf{2 8}$ selectively based on the preference of the TA; however, the second step is less selective, leading to $\mathbf{2 9}$ as a mixture of diastereomers. Luckily, the reversibility of the IMAMR enables epimerization, providing the product 29 with $>99 \%$ diastereomeric excess (de). If starting from 30, only one center of asymmetry is formed, since the other substituent in $\mathbf{3 2}$ is attached to the ring with a double bond. Thus, the forming enantiopure 32 can be employed in carboannulation reactions for the synthesis of various chiral alkaloids.

Exploiting the ability of amines to form Shiff's base in the presence of carbonyl groups, the intramolecular reaction represents a method for cyclization to gain access to 3D N-heterocycles. Simon and coworkers thoroughly investigated the synthesis of 2,6-disubstituted piperidine derivatives starting from diketones (Figure 7) [46-48].

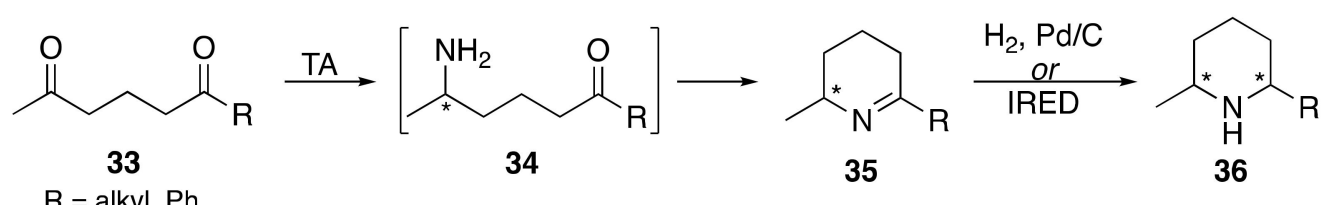

Figure 7. Transaminase-mediated synthesis of piperidine derivatives from diketones.

A regio- and enantiotope selective monoamination on the less bulky end of $\mathbf{3 3}$ leads to the formation of 34, which than undergoes spontaneous dehydrative cyclization to form enantiopure 35. Employing a diastereotope selective reduction $\left(\mathrm{H}_{2}, \mathrm{Pd} / \mathrm{C}\right)$, the second center of asymmetry can be established, and 36 can be synthesized with perfect diastereotope selectivity. With this method applying catalysts of different selectivities, all four stereoisomers of the alkaloid dihydropinidine $(36, \mathrm{R}=n-\mathrm{Pr})$ could be synthesized in three steps, while chemical methods suffered from long reaction sequences [47]. Furthermore, choosing appropriate cosolvents, the alkaloid isosolenopsin $\left(36, \mathrm{R}=n-\mathrm{C}_{9} \mathrm{H}_{19}\right)$ could also be synthesized [48]. Alternatively, an enzyme cascade employing TA with imine reductase (IRED) also led to the desired dihydropinidine (36) [49]; however, this method was considerably more expensive and tedious than using chemical reduction.

Similarly to the previous example, 2,5-disubstituted pyrrolidine derivatives with multiple centers of asymmetry can be prepared starting from the appropriate ketone (37) 
(Figure 8) [50]. However, since in this case the reduction with $\mathrm{H}_{2}, \mathrm{Pd} / \mathrm{C}$ was not sufficiently diastereotope selective, the authors opted for a nonselective reduction of $\mathbf{3 8}$ to achieve 39 . Then, the employed regio- and diastereotope selective monoamine oxidase (MAO-N) converted the undesired diastereomer $(S, S)-39$ back to 38, closing the DKR loop, while $(S, R)-39$ accumulated. The TA-IRED cascade has also been reported; however, the same limitation applies for this reaction as well [49].

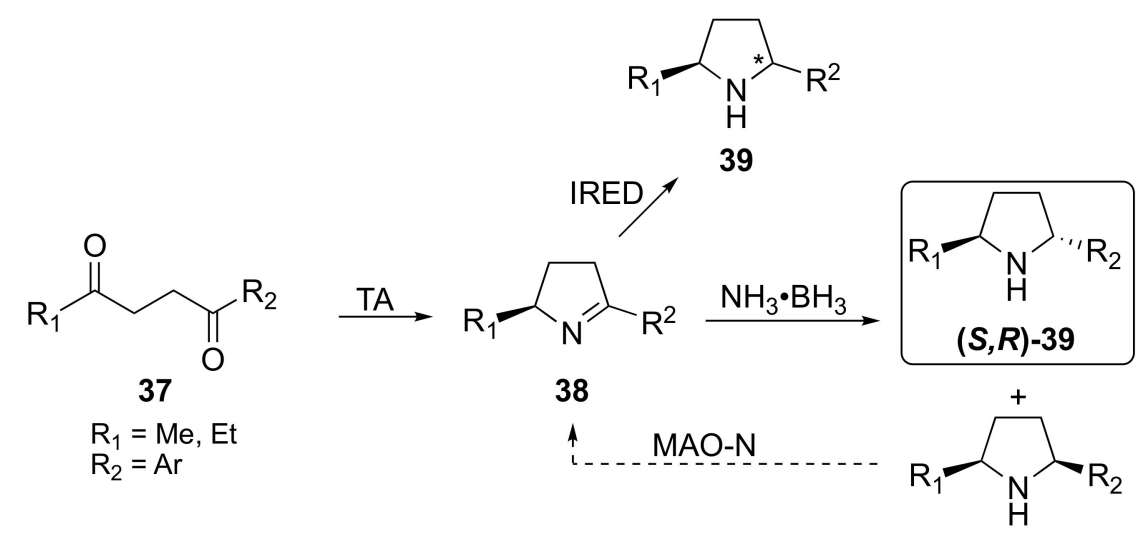

$(S, S)-39$

Figure 8. TA-mediated synthesis of pyrrolidine derivatives from diketones.

A more general method for the synthesis of 2-substituted and 2,2-, 2,3- and 2,4disubstituted piperidines and 2-substituted pyrrolidines was described starting from keto acids (40) (Figure 9) [49].

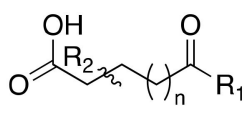

40

$\mathrm{n}=0,1$

$\mathrm{R}_{1}=\mathrm{Ar}$

$\mathrm{R}_{2}=\mathrm{H}$, Alky<smiles>C1CCCCC1</smiles><smiles>[R5]C([Y])CCC=O</smiles>

41<smiles>C1CCC2NCCCC2C1</smiles>

44<smiles>[R]C1=NCCC([R])C1=NC</smiles>

42<smiles>c1cc[nH+]cc1</smiles><smiles>[R2]C1CNC(Br)=C(Br)C1</smiles>

43

Figure 9. Three-enzyme cascade for the synthesis of saturated $N$-heterocycles.

The first enzyme of the one-pot, three-enzyme cascade is the carboxylic acid reductase (CAR), which promotes the formation of aldehyde 41, which in turn undergoes a similar transamination and dehydrative cyclization as that shown in Figure 8 to access 42 . Finally, an IRED is employed to synthesize 43. Starting from enantiopure 40, a single isomer could be produced with good $e e$ and $d e$. Since the TA-catalyzed step required an additional LDH/GDH alanine recycling system, a whole-cell de novo enzyme cascade was developed in which all the necessary enzymes and cofactors could be found inside the whole cell [51]. Furthermore, employing the in vivo system made it possible to screen for more complex molecules, such as bicyclic 44 and thiomorpholine derivative 45 .

Because of the widespread application of in vitro high-throughput screenings (HTSs) and the increasing complexity of drug candidates, chiral scaffolds containing 3D heterocycles have received more and more attention. Examples illustrating the importance of chiral, 3D heterocycle-containing scaffolds are the druglike, potent and selective P2X purinoceptor $3\left(\mathrm{P}_{2} \mathrm{X}_{3}\right)$ receptor antagonist $\mathrm{RO}-85(46)$ [52] and the lysophosphatidic acid receptor 2 (LPA 2 /EDG4) antagonist 47 with potential anticancer activity (Figure 10). In addition, other 3D heterocycles allowing derivatization at one nitrogen, such as morpholine and piperidine, appeared in reported HTS hits such as the Cancer Osaka thyroid kinase 
inhibitor (48) [53], the mineralocorticoid receptor antagonist (49) [54] or antimalarial agents against drug-resistant strains (50a-b) [55].<smiles>[R]CC(C)Nc1ccnc2cc(Cl)ccc12</smiles>

Figure 10. Chiral drug candidates and HTS hits containing 3D-amine heterocycles with substituents bearing asymmetric amine functionality.

Even though these small heterocycle-bearing chiral scaffolds have appeared in multiple drug candidates, all current "traditional" chemical methods for their synthesis exploit the chiral pool (Figure 11).

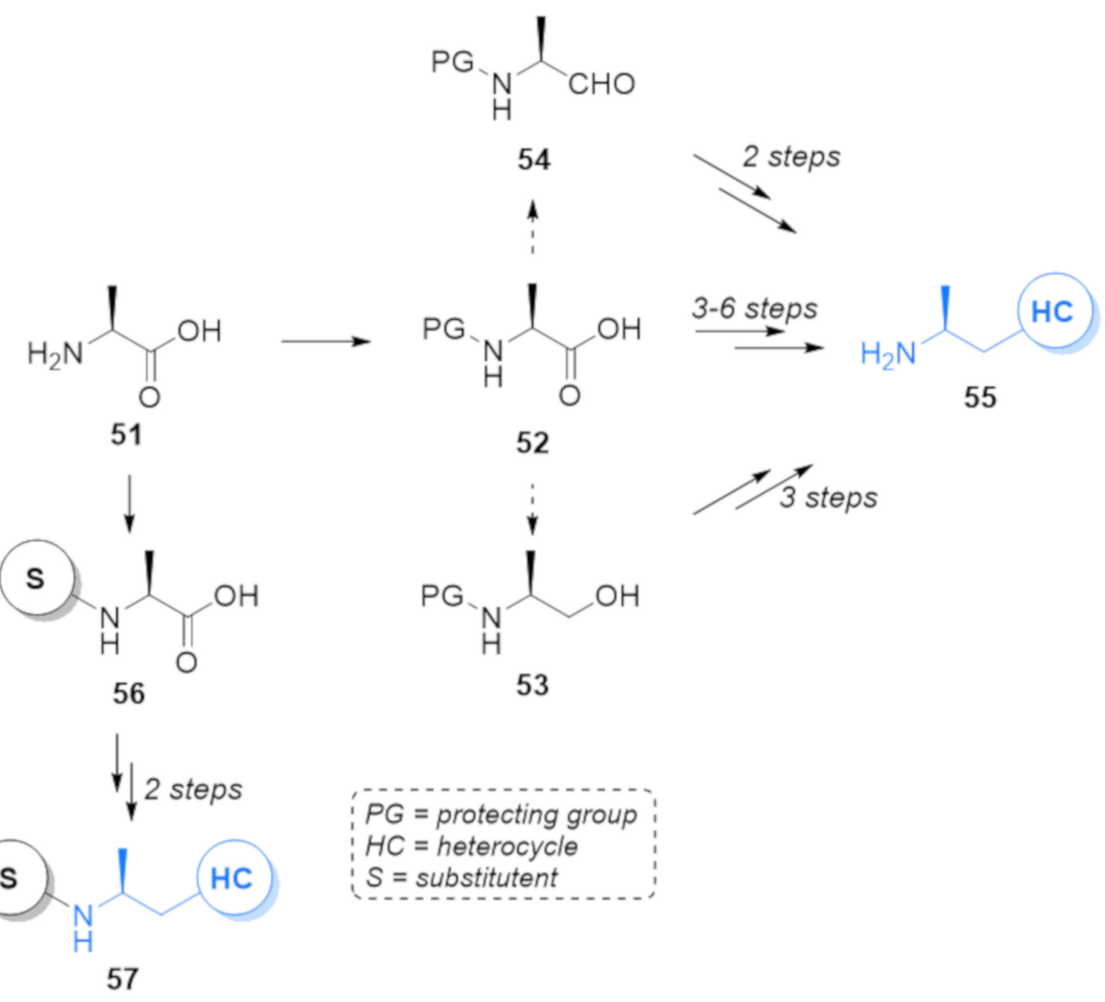

Figure 11. "Traditional" chemical synthesis of chiral 3D heterocycle-containing scaffolds.

Chiral alanine (51) [55-58], or its amino alcohol (53) [59] or amino aldehyde (54) derivatives [52], can serve as chiral building blocks for the synthesis of the target compound (55). 
The most reported method is the preparation of $\mathbf{5 5}$ starting from $\mathbf{5 1 ,} \mathbf{5 3}$ or $\mathbf{5 4}$ in 2-6 steps, depending on the availability of the starting material, while further substitution of the amine functional group follows. However, to eliminate protection and deprotection, the derivatization of the amine moiety (56) followed by carboxylic acid group manipulations results directly in 57 [57].

In this study, our aim was to widen the synthetic toolbox for chiral 3D amine heterocycles by developing the TA-mediated asymmetric synthesis of 55a-g starting from their respective prochiral ketones 57a-g (Figure 12), without the need for chiral pool.

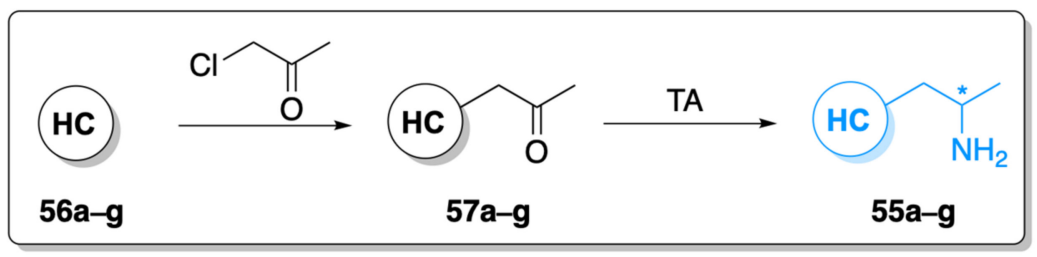

$\mathbf{H C}=$<smiles>CC1CCNCC1</smiles><smiles>CC(C)(C)OC(=O)N1CCNCC1</smiles><smiles>c1ccc(N2CCNCC2)cc1</smiles>

Figure 12. General reaction scheme for the synthesis of the target chiral 3D amine heterocycles.

\section{Results and Discussion}

\subsection{Screening the Activity of TAs with Morpholine Derivative 57a}

For initial screening, the morpholine derivative 57a was tried with the complete Codex ${ }^{\circledR}$ Amine Transaminase Kit involving (S)-selective TAs (Table 1 ) and $(R)$-selective TAs (Table 2). Reaction conditions were based on the proposed conditions provided by Codexis (10 mM substrate concentration with 100 equiv. IPA); however, TA load was reduced fivefold to better distinguish between TA performances. These screens allowed discarding TAs with poor enantioselectivity (Entries 8 and 9, in Table 2) or insufficient activity (e.g., Entries 4 and 6 in Table 1 or Entries 1 and 8 in Table 2). For further study, TAs were chosen that exhibited higher than $80 \%$ conversion after $24 \mathrm{~h}$ in the initial screen.

In several instances, the possibility of reducing the amine donor equivalent from 100- fold to 10-fold was explored. Unfortunately, the 10-fold reduction in the IPA amount resulted in a considerable drop in conversion in most cases (e.g., Entries 8 and 25 in Table 1 or Entries 4 and 14 in Table 2). The 10-fold reduction in IPA excess resulted in a minor drop in conversion only in a few instances, e.g., for TA-133 (Entry 2 in Table 1). Thus, the higher amine donor content was necessary to push the equilibrium of transamination towards full conversion. Alternatively, the substrate concentration was increased while using 100 equiv. of IPA. Interestingly, at $25 \mathrm{mM}$ substrate concentration, the high conversions observed with the initial screening conditions were either maintained with several TAs (Entries 9, 14, 18, 22 and 26 in Table 1 or Entry 5 in Table 2) or diminished almost completely with other TAs (Entry 3 in Table 1 or Entries 15 and 18 in Table 2). Only one (R)-selective TA (TA-025) operated under these conditions, while four (S)-TAs (TA-251, TA-254, TA-256 and TA-260) gave almost full conversions. Further increase in the substrate concentration to $50 \mathrm{mM}$ (and therefore further increase in the amine donor content) allowed the selection of three (S)-selective TAs that could operate under these conditions and still produce the desired

(S)-55a with full conversion (Entries 19, 23 and 27 in Table 1); however, no (R)-selective TA could catalyze the formation of $(R)-55$ a under these conditions.

Noteworthy, increasing substrate concentration led to increased organic content in the reaction mixtures (Table S2), which in case of $50 \mathrm{mM}$ substrate concentration with 100 equiv. of IPA exceeded $40 v / v \%$. According to the TA Kit information sheet provided by Codexis, $\sim 50 \%$ of the TAs lose activity above $20 v / v \%$ dimethyl sulfoxide (DMSO). Therefore, rather than changing IPA content with the substrate concentration, the IPA content was fixed at $25 v / v \%$ (3 M). In this way, the substrate concentration could be increased up to $100 \mathrm{mM}$ 
at this fixed IPA content. Therefore, besides the best three (S)-TAs (TA-254, TA-256 and TA-260), the (R)-selective TA-025 was also included for further optimization, as this TA maintained some activity at $21 v / v \%$ IPA (Entry 6 in Table 2).

\subsection{Screening the Effect of Substrate Concentration with the 1-Morpholinopropan-2-one (57a)}

The four Tas chosen for further studies were screened for the transamination of $57 \mathbf{a}$ at five different substrate concentrations ranging between $10-100 \mathrm{mM}$ in reactions with fixed IPA content (25 $v / v \%)$ (Figure 13).

Table 1. Activity screening with the (S)-selective TAs of the Codex ${ }^{\circledR}$ Amine Transaminase Screening Kit in transamination of 1-morpholinopropan-2-one (57a).<smiles>CC(=O)C[NH+]1CCOCC1Cl</smiles>

$57 \mathrm{a} \cdot \mathrm{HCl}$<smiles>C[C](N)CN1CCOCC1</smiles>

(S)-55a

\begin{tabular}{|c|c|c|c|c|c|}
\hline Entry & TA & $\begin{array}{l}\text { Substrate Conc. } \\
(\mathrm{mM})\end{array}$ & $\begin{array}{c}\text { IPA Equiv. } \\
(-)\end{array}$ & $\begin{array}{c}c \\
(\%)\end{array}$ & $\begin{array}{c}\text { ee } \\
(\%)\end{array}$ \\
\hline 1 & 113 & 10 & 100 & 93 & $>99$ \\
\hline 2 & & 10 & 10 & 92 & $>99$ \\
\hline 3 & & 25 & 100 & 0 & $>99$ \\
\hline 4 & 200 & 10 & 100 & 24 & $>99$ \\
\hline 5 & 217 & 10 & 100 & 76 & $>99$ \\
\hline 6 & 234 & 10 & 100 & 24 & $>99$ \\
\hline 7 & 237 & 10 & 100 & 98 & $>99$ \\
\hline 8 & & 10 & 10 & 48 & $>99$ \\
\hline 9 & & 25 & 100 & 94 & $>99$ \\
\hline 10 & & 50 & 100 & 0 & $>99$ \\
\hline 11 & 238 & 10 & 100 & 41 & $>99$ \\
\hline 12 & 251 & 10 & 100 & 99 & $>99$ \\
\hline 13 & & 10 & 10 & 92 & $>99$ \\
\hline 14 & & 25 & 100 & 99 & $>99$ \\
\hline 15 & & 50 & 100 & 23 & $>99$ \\
\hline 16 & 254 & 10 & 100 & 99 & $>99$ \\
\hline 17 & & 10 & 10 & 86 & $>99$ \\
\hline 18 & & 25 & 100 & 99 & $>99$ \\
\hline 19 & & 50 & 100 & 99 & $>99$ \\
\hline 20 & 256 & 10 & 100 & 99 & $>99$ \\
\hline 21 & & 10 & 10 & 85 & $>99$ \\
\hline 22 & & 25 & 100 & 99 & $>99$ \\
\hline 23 & & 50 & 100 & 99 & $>99$ \\
\hline 24 & 260 & 10 & 100 & 99 & $>99$ \\
\hline 25 & & 10 & 10 & 34 & $>99$ \\
\hline 26 & & 25 & 100 & 99 & $>99$ \\
\hline 27 & & 50 & 100 & 99 & $>99$ \\
\hline 28 & P1-B04 & 10 & 100 & 17 & $>99$ \\
\hline 29 & P1-F03 & 10 & 100 & 53 & $>99$ \\
\hline 30 & P1-G05 & 10 & 100 & 4 & $>99$ \\
\hline
\end{tabular}

Reaction conditions: Total volume: $1 \mathrm{~mL}, 57 \mathrm{a} . \mathrm{HCl}(10-50 \mathrm{mM})$, IPA (10-100 equiv.), TA ( $2 \mathrm{mg})$, pyridoxal phosphate (PLP) (1 mM), potassium phosphate (KPi) buffer $(100 \mathrm{mM}, \mathrm{pH} 7.5)$, at $30{ }^{\circ} \mathrm{C}$ for $24 \mathrm{~h}$. 
Table 2. Activity screening with the $(R)$-selective TAs of the Codex ${ }^{\circledR}$ Amine Transaminase Screening Kit in transamination of 1-morpholinopropan-2-one (57a).

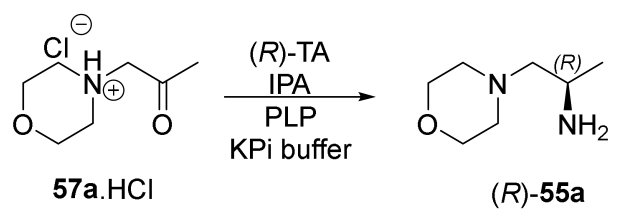

\begin{tabular}{|c|c|c|c|c|c|}
\hline Entry & TA & $\begin{array}{l}\text { Substrate Conc. } \\
\text { (mM) }\end{array}$ & $\begin{array}{l}\text { IPA Equiv. } \\
(-)\end{array}$ & $\begin{array}{c}c \\
(\%)\end{array}$ & $\begin{array}{l}\text { ee } \\
(\%)\end{array}$ \\
\hline 1 & 007 & 10 & 100 & 2 & $>99$ \\
\hline 2 & 013 & 10 & 100 & 46 & $>99$ \\
\hline 3 & 025 & 10 & 100 & 93 & $>99$ \\
\hline 4 & & 10 & 10 & 48 & $>99$ \\
\hline 5 & & 25 & 100 & 93 & $>99$ \\
\hline 6 & & 50 & 100 & 4 & $>99$ \\
\hline 7 & 117 & 10 & 100 & 13 & $>99$ \\
\hline 8 & 301 & 10 & 100 & 6 & 74 \\
\hline 9 & 303 & 10 & 100 & 11 & 90 \\
\hline 10 & 412 & 10 & 100 & 41 & $>99$ \\
\hline 11 & 415 & 10 & 100 & 54 & $>99$ \\
\hline 12 & P2-A01 & 10 & 100 & 40 & $>99$ \\
\hline 13 & P2-A07 & 10 & 100 & 82 & $>99$ \\
\hline 14 & & 10 & 10 & 42 & $>99$ \\
\hline 15 & & 25 & 100 & 10 & $>99$ \\
\hline 16 & P2-B01 & 10 & 100 & 85 & 99 \\
\hline 17 & & 10 & 10 & 71 & $>99$ \\
\hline 18 & & 25 & 100 & 4 & $>99$ \\
\hline
\end{tabular}

Reaction conditions: Total volume: $1 \mathrm{~mL}, 57 \mathrm{a} . \mathrm{HCl}$ (10-50 mM), IPA (10-100 equiv.), TA (2 mg), PLP (1 mM), KPi buffer (100 mM, pH 7.5), at $30{ }^{\circ} \mathrm{C}$ for $24 \mathrm{~h}$.

Reactions with the $(R)$-selective TA-025 (Figure 13a) reached high conversions al-ready after $4 \mathrm{~h}$ and $>85 \%$ conversion after $24 \mathrm{~h}$ in all cases. Comparing the $92 \%$ conversion achieved at $50 \mathrm{mM}$ with fixed IPA content $(25 \mathrm{v} / \mathrm{v} \%$, 61 equiv.) to the only $4 \%$ conversion with 100 equiv. IPA (41 v/v\%: Entry 6 in Table 2 ) indicated that organic content of the reaction played a quite significant effect on the outcome of the transamination. Interestingly, with the $(R)$-selective TA-025 full conversion was not observed (Figure 13a), while all three (S)-selective Tas (Figure 13b-d) resulted in $>98 \%$ conversion up to $50 \mathrm{mM}$ substrate concentration indicating a difference in reaction equilibria. Furthermore, in case of TA254 (Figure 13b) and TA-256 (Figure 13c) the reaction at $100 \mathrm{mM}$ substrate concentration exceeded $90 \%$ conversion. This concentration representing 10 -fold increase compared to the initial screening corresponds to $17.8 \mathrm{mg} / \mathrm{mL}$ of 57a. Even though TA-254 (Figure 13b) and TA-256 (Figure 13c) did not show differences in conversions when looking after $24 \mathrm{~h}$, it is apparent that at lower substrate concentrations (10 and $25 \mathrm{mM}$ ) TA-256 should be favored, while TA-254 resulted in higher conversions at increased substrate concentrations.

\subsection{Screening the Best Transaminases with Further Heterocycle-Containing Ketones (57b-g)}

Screening of the further heterocyclic ketones $57 \mathrm{~b}-\mathrm{g}$ was performed in a similar manner (Figures S1-S6). In Table 3, the best results achieved with each heterocyclic ketone substrates $57 \mathbf{b}$-g are summarized with the (S)-selective TAs. Because of the favorable solubility properties of saturated heterocycle derivatives in aqueous media, even $57 \mathrm{f}$ and $57 \mathrm{~g}$ could be dissolved without the need of cosolvent. 


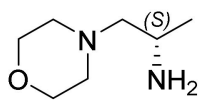

(S)-55a

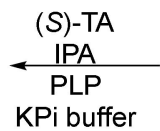

KPi buffer

TA-025

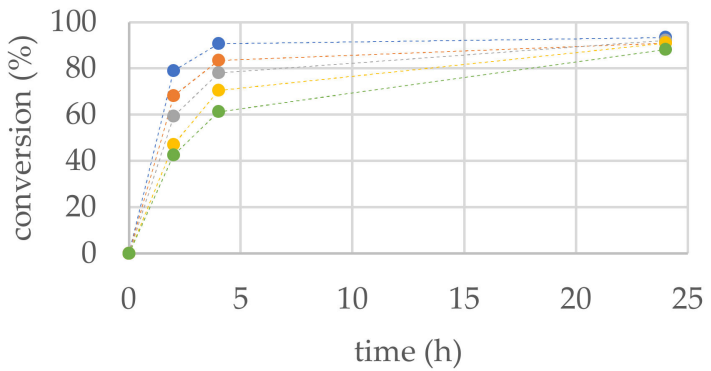

$\bullet-10 \mathrm{mM} \quad-\quad \bullet \quad 25 \mathrm{mM} \quad \cdots \quad \bullet-50 \mathrm{mM}$

• $75 \mathrm{mM} \quad \cdots \cdots \cdot-\cdots \cdot 100 \mathrm{mM}$

(a)

TA-256

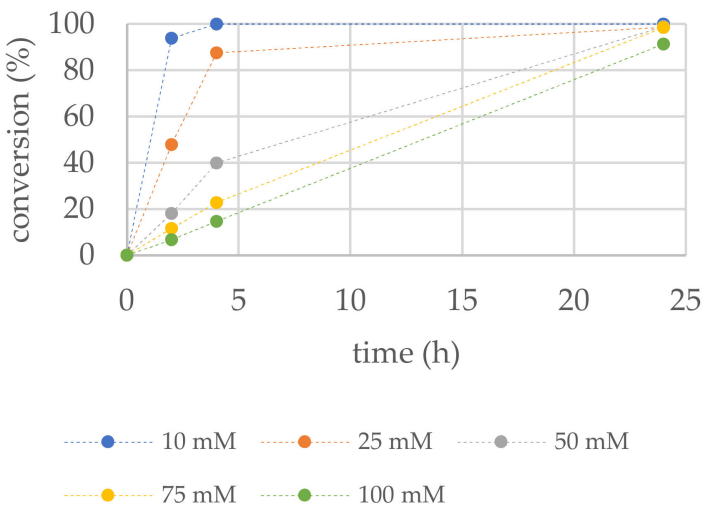

(c)

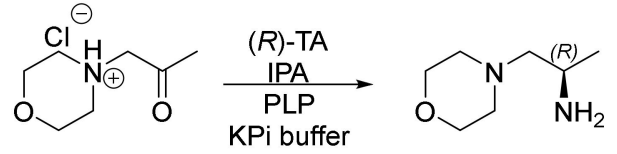

$(R)-55 a$

TA-254

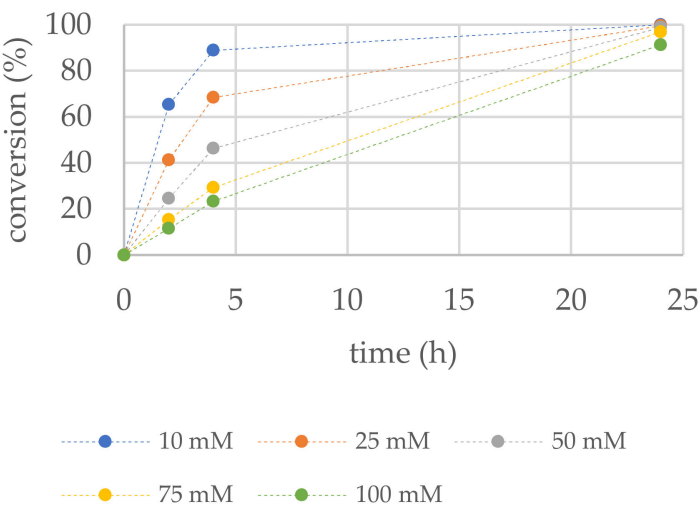

(b)

TA-260

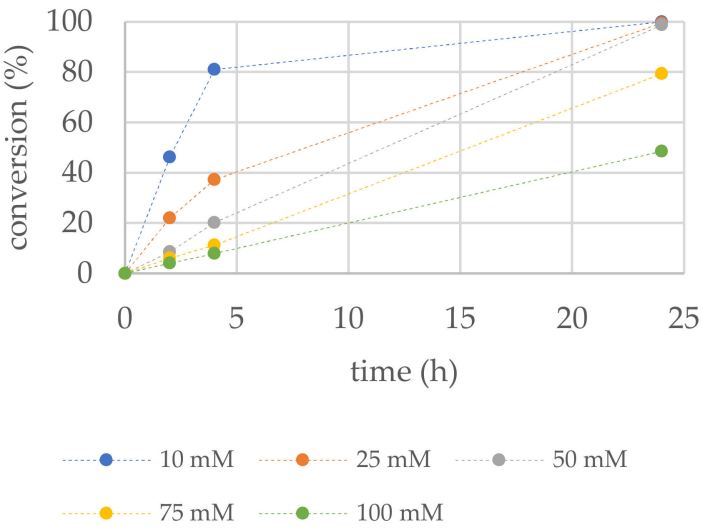

(d)

Figure 13. Effect of substrate concentration in transamination of the ketone 57a catalyzed by (a) (R)-TA-025, (b) (S)-TA-254, (c) (S)-TA-256 and (d) (S)-TA-260. Reaction conditions: Total volume: $1 \mathrm{~mL}, 57 \mathrm{a} . \mathrm{HCl}(10-100 \mathrm{mM}), \mathrm{IPA}(25 \mathrm{v} / \mathrm{\%}), \mathrm{TA}(2 \mathrm{mg})$, PLP (1 mM), KPi buffer (100 mM, pH 7.5), at $30^{\circ} \mathrm{C}$ for $24 \mathrm{~h}$.

Comparing the thiomorpholine derivative $57 \mathrm{~b}$ (Figure S1) to the morpholine derivative 57a (Figure 13), a decrease in activity was observed with the $(R)$-selective TA-025 (a) and two (S)-selective TAs (TA-254: $\mathbf{b}$ and TA-256: $\mathbf{c}$ ), while the (S)-selective TA-260 (d) showed almost identical conversion values with the two substrates. The $24 \mathrm{~h}$ reactions reached full conversion only below $50 \mathrm{mM}$ substrate concentration, with the largest decrease observed using TA-256, producing (S)-55b only with $40 \%$ conversion. The best performing TA with the thiomorpholine derivative $57 \mathrm{~b}$ was TA-254, enabling $90 \%$ conversion at $75 \mathrm{mM}$ (Table 3, Entry 4). The transamination of the piperidine ketone 57c (Figure S2) happened with somewhat lower degree of conversion at lower substrate concentrations compared to 57a; however, similarly high conversions were reached after $24 \mathrm{~h}$. The best performing TA was TA-256, reaching $91 \%$ conversion at $75 \mathrm{mM}$ (Table 3, Entry 9). Unlike the patterns of conversion over time observed with $57 \mathrm{a}-\mathbf{c}$, the pattern of conversion for the piperazine derivative $\mathbf{5 7 d}$ showed an almost linear correlation between conversion and time within $24 \mathrm{~h}$ (Figure S3), albeit reaching >90\% conversion with TA-254 (b) and 
TA-256 (c) with up to $50 \mathrm{mM}$ (Table 3, Entry 13). Replacing the relatively small methyl substituent with the much bulkier tert-butoxycarbonyl protecting group in ketone 57e resulted in much higher conversions than with $\mathbf{5 7 d}$ with all four TAs (Figure S4). Although full conversion could not be reached from 57d, TA-254 (b) and TA-256 (c) could provide $>90 \%$ conversion even at $100 \mathrm{mM}$ substrate concentration (Table 2, Entry 20), similarly to 57a. The phenyl-substituted piperazine ketone $\mathbf{5 7 f}-$ extended with a 2D aromatic ring of no flexibility-underwent transamination with similar progress as the model compound 57a (Figure S5). However, the ( $R$ )-selective TA-025 allowed high conversions only up to $50 \mathrm{mM}$ substrate concentration (Figure S5, a), while the best-performing TA-256 (Table 3, Entries 21-25) enabled $>90 \%$ conversion at substrate concentrations up to $100 \mathrm{mM}$. Finally, the benzyl-protected piperazine derivative $57 \mathrm{~g}$ - with a more flexible 2D aromatic ringcontaining group - was also screened (Figure S6). Interestingly, the activities observed were partially reflective of the results achieved with methyl-substituted $57 \mathrm{c}$ and phenylsubstituted 57f. TA-025 (a) and TA-260 (d) followed close to linear conversion in time, while TA-254 (b) exceeded 90\% conversion in all cases (Table 3, Entries 26-30), being the best TA for this substrate. Although optimization reactions with 57a using TA-025 revealed practically exclusive enantiotope selectivity under all conditions, in the cases of substrates $57 \mathrm{c}$ and $\mathbf{5 7 f}$, the degree of enantiotope selectivity decreased, lowering the enantiomeric excess to $94 \%$ in the worst case for $(S)-55$ c.

The results of the transamination of 57a-g indicated that the properties of the atom and its substituent(s) in $\gamma$-position from $\mathrm{N}$-atom bearing the asymmetric amine side chain in the saturated heterocycle significantly affected the outcome of the asymmetric reactions. While in case of TA-254, the change of an oxygen atom (in 57a) to sulfur (57b) or a methylsubstituted carbon (57c) affected the activity only slightly, with excellent enantiotope selectivity, a methyl or benzyl substitution of the piperazine ring ( $57 \mathrm{~d}$ and $57 \mathrm{~g}$, respectively) resulted in substantially decreased activity in most cases. Interestingly, with other bulky substituents, such as $t$-butoxycarbonyl or phenyl (57e and $\mathbf{5 7 f}$, respectively), the initial activities were considerably higher, although at elevated substrate concentrations, limited conversions could be reached in all cases. It was also indicated that TA-254 and TA-256 could transform substrates bearing larger substituents such as the phenyl-substituted $\mathbf{5 7 f}$ and the benzyl-substituted $\mathbf{5 7 g}$ even at high substrate concentrations.

Our results with Codexis TAs using $100 \mathrm{mM}$ substrate concentration with $2 \mathrm{mg} / \mathrm{mL}$ enzyme loading proved to be superior to those obtained in previous studies, which applied in all cases cosolvents in aqueous media and lower substrate concentration [26,60], higher weight percent TA [61] or coupled equilibrium-shifting methods [62].

Since the $(R)$-selective TA-025 did not provide in all cases the enantiopure $(R)$-amine, the preparative scale reactions and isolation of the forming $(R)$-amines $((R)-55 \mathbf{a}-\mathbf{g})$ were not performed with any $(R)$-selective TA in this study. Expectedly, however, the same sequence of preparative scale transamination followed by isolation could be applied with a proper $(R)$-TA as for preparative scale biotransformations with the (S)-selective TAs, yielding the corresponding (S)-amines (S)-55a-g reported in Table 4.

The challenge in the isolation of amines (S)-55a-g was the high solubility of the produced amines with 3D heterocycle units, especially when a heteroatom or a small substituent was present in $\gamma$-position from the $N$-atom bearing the asymmetric amine side chain, such as in the cases of 55a-d (Entries 1-4 in Table 4). Moreover, the starting ketones $57 \mathbf{a}-\mathrm{g}$ could not be separated from the products $((S)-55 \mathbf{a}-\mathrm{g})$ by simple acidic extraction, since both the substrate and the product contained amine functions. However, with extensive extraction, the products $((S)-55 \mathbf{a}-\mathbf{g})$ could be transferred to the organic phase in good-to-excellent yield and in high purity. Importantly, the use of $(S)$-selective TA-254 or TA-256 allowed the preparation of all the target $(S)$-amines with 3D heterocycle units $[(S)-55 a-g]$ in enantiopure form (Table 4). 
Table 3. Asymmetric transamination of the heterocyclic ketones $\mathbf{5 7} \mathbf{b}-\mathbf{g}$ with the best performing $(S)$-selective TAs.

\begin{tabular}{|c|c|c|c|c|c|}
\hline & & $57 \mathrm{~b}-\mathrm{g}$ & (S)-55b-g & & \\
\hline Entry & Substrate & TA & $\begin{array}{c}\text { Substrate } \\
\text { Concentration } \\
(\mathrm{mM})\end{array}$ & $\begin{array}{c}\text { c } \\
(\%)\end{array}$ & $\begin{array}{c}\text { ee } \\
\text { (\%) }\end{array}$ \\
\hline 1 & & & 10 & 98 & $>99$ \\
\hline 2 & & & 25 & 98 & $>99$ \\
\hline 3 & & TA-254 & 50 & 97 & $>99$ \\
\hline 4 & & & 75 & 90 & $>99$ \\
\hline 5 & 57b. $\mathrm{HCl}$ & & 100 & 77 & $>99$ \\
\hline 6 & & & 10 & 96 & $>99$ \\
\hline 7 & & & 25 & 95 & $>99$ \\
\hline 8 & & TA-256 & 50 & 95 & $>99$ \\
\hline 9 & & & 75 & 91 & $>99$ \\
\hline 10 & 57c. $\mathrm{HCl}$ & & 100 & 83 & $>99$ \\
\hline 11 & & & 10 & 97 & $>99$ \\
\hline 12 & & & 25 & 95 & $>99$ \\
\hline 13 & & TA-256 & 50 & 95 & $>99$ \\
\hline 14 & & & 75 & 89 & $>99$ \\
\hline 15 & 50d.2 & & 100 & 88 & $>99$ \\
\hline 16 & & & 10 & 94 & $>99$ \\
\hline 17 & & & 25 & 94 & $>99$ \\
\hline 18 & & TA-256 & 50 & 94 & $>99$ \\
\hline 19 & & & 75 & 94 & $>99$ \\
\hline 20 & & & 100 & 93 & $>99$ \\
\hline 21 & & & 10 & 96 & $>99$ \\
\hline 22 & & & 25 & 95 & $>99$ \\
\hline 23 & & TA-256 & 50 & 95 & $>99$ \\
\hline 24 & & & 75 & 93 & $>99$ \\
\hline 25 & -5 & & 100 & 93 & $>99$ \\
\hline 26 & & & 10 & 93 & $>99$ \\
\hline 27 & & & 25 & 92 & $>99$ \\
\hline 28 & & TA-254 & 50 & 92 & $>99$ \\
\hline 29 & & & 75 & 92 & $>99$ \\
\hline 30 & $57 \mathrm{~g}$ & & 100 & 91 & $>99$ \\
\hline
\end{tabular}

Reaction conditions: Total volume: $1 \mathrm{~mL}, \mathbf{5 7 b}-\mathbf{g}(. \mathrm{HCl})$ (10-100 mM as indicated), IPA (25 v/v\%), TA (2 mg), PLP (1 mM), KPi buffer (100 mM, $\mathrm{pH} 7.5)$, at $30^{\circ} \mathrm{C}$ for $24 \mathrm{~h}$.

\subsection{Structural Stabilization of the Tertiary Amine Bearing the Asymmetric Amine Side Chain}

The ${ }^{1} \mathrm{H}$ and ${ }^{13} \mathrm{C}$ nuclear magnetic resonance (NMR) spectra of the isolated $(S)-1-(4-$ methylpiperidin-1-yl)propan-2-amine $(S)$-55c revealed surprising complexity as compared to the other amines (Figure S7a). Usually, the low energy barrier of the nitrogen inversion prevents the tertiary nitrogen from existing as a stable stereogenic element (e.g., a center of asymmetry or pseudoasymmetry). However, this type of inversion can be diminished if the lone electron pair of the tertiary nitrogen is fixed by a hydrogen bond. Our modelling using Avogadro [63] indicated that the propan-2-amine side chain allows a distance between the primary amine hydrogens and the tertiary nitrogen of the 3D heterocycle and thereby stabilization of the $\mathrm{N}$-center via a H-bond in each product. This stabilization, however, results in no apparent consequences in the heterocyclic amine products-with exception of the methyl-substituted piperidine $55 \mathbf{c}$ - because of the substitution pattern (in $\mathbf{5 5 a} \mathbf{a}, \mathbf{b}$ ) or the presence of another nonfixed tertiary $N$-atom (in $55 \mathrm{~d}-\mathrm{g}$ ) disallowing the existence of any stable stereogenic unit. As the $2.53 \AA$ distance between the $\mathrm{H}$ atom of the propan-2-amine side-chain's amine and the tertiary nitrogen in the major trans-isomer trans-55c corresponds to a strong H-bond (Figure 14), this stabilization became apparent in the case of the NMR 
spectra of methyl-substituted piperidine 55c, allowing the detection of cis-55c and trans-55c because their lifetimes well exceeded the timescale of the NMR measurements.

Table 4. Production of enantiopure $(S)$-amines $[(S)$-55a-g] at preparative scale with the best performing $(S)$-selective TAs.

\begin{tabular}{|c|c|c|c|c|c|}
\hline & & $57 a-g$ & $(S)-55 a$ & & \\
\hline Entry & Substrate $^{a}$ & TA & $\begin{array}{c}\text { Yield a }^{a} \\
(\%)\end{array}$ & $\begin{array}{l}e^{b} \\
(\%)\end{array}$ & {$[\alpha](\mathrm{c})^{\mathrm{c}}$} \\
\hline 1 & $57 a$ & TA-254 & 47 & $>99$ & $+31.2(1.12)$ \\
\hline 2 & $57 b$ & TA-254 & 74 & $>99$ & $+44.0(0.64)$ \\
\hline 3 & $57 c$ & TA-256 & 83 & $>99$ & $+34.2(1.20)$ \\
\hline 4 & $57 d$ & TA-256 & 65 & $>99$ & $+36.6(1.20)$ \\
\hline 5 & $57 e$ & TA-256 & 59 & $>99$ & $+29.4(1.20)$ \\
\hline 6 & $57 f$ & TA-256 & 81 & $>99$ & +36.0 (1.20) \\
\hline 7 & $57 \mathrm{~g}$ & TA-254 & 94 & $>99$ & $+26.9(1.20)$ \\
\hline
\end{tabular}

${ }^{a}$ Reaction conditions: Total volume: $5 \mathrm{~mL}, 57 \mathrm{a}-\mathrm{g}(50 \mathrm{mM})$, IPA (25 v/v $\left.\%\right)$, TA (10 mg), PLP (1 mM), KPi buffer $(100 \mathrm{mM}, \mathrm{pH} 7.5)$, at $30{ }^{\circ} \mathrm{C}$ for $24 \mathrm{~h} .{ }^{\mathrm{b}}$ Determined by GC using chiral column. ${ }^{\mathrm{c}}$ At sodium D-line, $20{ }^{\circ} \mathrm{C}$, solvent: methanol.

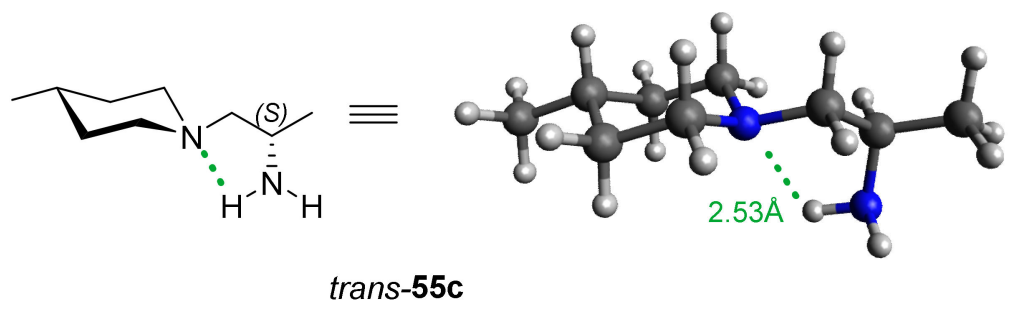

Figure 14. Stabilization of trans-55c by H-bond formation.

Since the increase in the proton-exchange rate decreases the lifetime of the stable stereoisomeric forms in acidic environments due to the rapid proton-exchange rate at the amine functions, the consequences of H-bond stabilization could be suppressed. Accordingly, gradual addition of acid to the sample of 55c simplified the ${ }^{1} \mathrm{H}$ NMR spectrum (Figure S6c).

\section{Materials and Methods}

\subsection{Materials and Biocatalysts}

If not stated otherwise, all chemicals and starting materials were purchased from Sigma-Aldrich (St. Louis, MO, USA), Fluka (Milwaukee, WI, USA) or Alfa Aesar Europe (Karlsruhe, Germany). The Codex ${ }^{\circledR}$ Amine Transaminase (ATA) Screening Kit containing 24 TAs was purchased from Codexis Inc.

\subsection{Analytical and Separation Methods}

NMR spectra were recorded in the indicated deuterated solvents on a Bruker DRX-500 spectrometer operating at 500 or $300 \mathrm{MHz}$ for ${ }^{1} \mathrm{H}$ and 126 or $75 \mathrm{MHz}$ for ${ }^{13} \mathrm{C}$. NMR signals were given in ppm on the $\delta$ scale. Infrared (IR) spectra were recorded on a Bruker ALPHA FT-IR spectrometer (in ATR mode), and wavenumbers $(v)$ of bands were listed in $\mathrm{cm}^{-1}$. Optical rotations were measured on a Perkin-Elmer 241 polarimeter at the D-line of sodium. The polarimeter was calibrated with measurements of both enantiomers of menthol. Thin layer chromatography (TLC) was carried out on precoated TLC ALUGRAM ${ }^{\circledR}$ Xtra SIL G/UV 254 sheets (Macherey-Nagel); spots were visualized under UV light (254 nm) and with ninhydrin staining. Column chromatography was carried out with Gerduran ${ }^{\circledR} \mathrm{Si}$ 60 (Merck) silica gel. Gas chromatographic (GC) analyses were performed with an Agilent 4890 gas chromatograph equipped with FID detector using $\mathrm{H}_{2}$ carrier gas (injector: $250{ }^{\circ} \mathrm{C}$, detector: $250^{\circ} \mathrm{C}$, head pressure: 12 psi, split ratio: 50:1) using Hydrodex $\beta-6 \mathrm{TBDM}$ column 
$(25 \mathrm{~m} \times 0.25 \mathrm{~mm} \times 0.25 \mu \mathrm{m}$ film of heptakis-(2,3-di-O-methyl-6-O-t-butyldimethylsilyl)$\beta$-cyclodextrin; Macherey and Nagel).

As experiments in triplicates with the model compound 57a indicated a variation within $2 \%$, the further optimization and conversion-time course experiments were performed as single series.

\subsection{Synthesis of the Heterocyclic Ketones (57a-g)}

The substrates (57a-d,f) and 4-(2-oxopropyl)piperazin-1-ium hydrochloride were synthesized according to the previously published method [64].

tert-Butyl 4-(2-oxopropyl)piperazine-1-carboxylate (57e). To a suspension of 4-(2-oxopropyl) piperazin-1-ium hydrochloride $(2.5 \mathrm{mmol})$ in tetrahydrofuran $(10 \mathrm{~mL})$, triethylamine ( $2.5 \mathrm{mmol}, 1.0$ equiv.) was added. After $5 \mathrm{~min}$ of stirring, di-tert-butyl dicarbonate ( $3 \mathrm{mmol}$, 1.2 equiv.) was added, and the reaction was stirred at room temperature. This was followed by conversion via TLC, and upon completion ( $30 \mathrm{~min})$, the solid residues were filtered off from the reaction, and the solvent was evaporated from the filtrate. To the crude residue, water $(10 \mathrm{~mL})$ was added, and the mixture was extracted with ethyl acetate $(3 \times 10 \mathrm{~mL})$. The combined organic phases were washed with brine, dried on sodium sulfate and concentrated under vacuum. The residual orange oil was purified by column chromatography (DCM:MeOH:35\% $\mathrm{NH}_{4} \mathrm{OH}$ 10:1:0.1) to yield the desired product as a yellow oil. Yield: $74 \%$; TLC $\left(\mathrm{R}_{\mathrm{f}}\right) 0.64$ (DCM:MeOH:35\% $\mathrm{NH}_{4} \mathrm{OH}$ 10:1:0.1); ${ }^{1} \mathrm{H}$ NMR $\left(500 \mathrm{MHz}, \mathrm{CDCl}_{3}\right) \delta 3.48(\mathrm{t}$, $J=5.1 \mathrm{~Hz}, 4 \mathrm{H}), 3.24(\mathrm{~s}, 2 \mathrm{H}), 2.47(\mathrm{t}, J=5.1 \mathrm{~Hz}, 4 \mathrm{H}), 2.14(\mathrm{~s}, 3 \mathrm{H}), 1.44(\mathrm{~s}, 9 \mathrm{H}) ;{ }^{13} \mathrm{C} \mathrm{NMR}$ $\left(126 \mathrm{MHz}, \mathrm{CDCl}_{3}\right) \delta 205.8,154.8,79.9,67.9,53.1,28.52,27.9 ; \mathrm{IR}\left(\mathrm{cm}^{-1}\right): 2975,2932,1686$, 1417, 1364, 1241, 1164, 1123, 1005.

1-(4-Benzylpiperazin-1-yl)propan-2-one (57g). To a solution of 4-(2-oxopropyl)piperazin1-ium hydrochloride $(2.5 \mathrm{mmol})$ in ethanol $(10 \mathrm{~mL})$, triethylamine $(5.0 \mathrm{mmol}, 2.0$ equiv.) was added. After addition of benzyl chloride ( $4.5 \mathrm{mmol}, 1.8$ equiv.), the reaction was stirred at room temperature. The progress of the reaction was followed by TLC, and upon completion $(2 \mathrm{~h})$, the solvent was evaporated. To the crude residue, water $(10 \mathrm{~mL})$ was added, and the mixture was extracted with ethyl acetate $(3 \times 10 \mathrm{~mL})$. The combined organic phases were washed with brine, dried on sodium sulfate and concentrated under vacuum. The residual orange oil was purified by column chromatography (DCM:MeOH:35\% $\mathrm{NH}_{4} \mathrm{OH}$ 10:1:0.1) to yield the desired product as a yellow oil. Yield: 52\%; TLC $\left(\mathrm{R}_{\mathrm{f}}\right) 0.68$ (DCM:MeOH:35\% $\left.\mathrm{NH}_{4} \mathrm{OH} 10: 1: 0.1\right) ;{ }^{1} \mathrm{H} \mathrm{NMR}\left(500 \mathrm{MHz}, \mathrm{CDCl}_{3}\right) \delta$ 7.35-7.28 (m, 4H), 7.31-7.21 (m, 1H), $3.54(\mathrm{~s}, 2 \mathrm{H}), 3.18(\mathrm{~s}, 2 \mathrm{H}), 2.54(\mathrm{bs}, 8 \mathrm{H}), 2.13(\mathrm{~s}, 3 \mathrm{H}) ;{ }^{13} \mathrm{C}$ NMR $\left(126 \mathrm{MHz}, \mathrm{CDCl}_{3}\right) \delta 206.6,129.4,128.4,127.3,77.4,77.2,76.9,68.3,63.0,53.4,52.8$, 27.9; IR ( $\left.\mathrm{cm}^{-1}\right): 2937,2809,2768,1712,1670,1453,1352,1154,1134,1010,739,696$.

\subsection{Screening the Asymmetric Transamination of the Ketone 57a with Codexis ${ }^{\circledR}$ TAs}

All screening reactions were performed at $30^{\circ} \mathrm{C}$ for $24 \mathrm{~h}$ in a $4 \mathrm{~mL}$ screw-cap vial with $1 \mathrm{~mL}$ reaction volume. To TA $(2 \mathrm{mg}), 100 \mu \mathrm{L}$ of the starting material stock solution $(100 \mathrm{mM}$ 57a. $\mathrm{HCl}$ and 1 equiv. $\mathrm{NaOH}$ ) and $900 \mu \mathrm{L}$ of amine donor stock solution (1.11 M IPA and $1.11 \mathrm{mM}$ PLP in potassium phosphate buffer $(100 \mathrm{mM}, \mathrm{pH}$ 7.5)) were added, resulting in the following final concentrations: $57 \mathrm{a} . \mathrm{HCl}(10 \mathrm{mM})$, IPA (1 M), PLP (1 mM). After $24 \mathrm{~h}$, a sample $(50 \mu \mathrm{L})$ of the reaction mixture was added to aqueous $\mathrm{NaOH}$ solution $(50 \mu \mathrm{L}, 5 \mathrm{~N})$ and ethyl acetate $(1 \mathrm{~mL})$. This was followed by the complete drying of the aqueous phase with sodium sulfate. The separated organic phase was derivatized with acetic anhydride $(10 \mu \mathrm{L})$, and conversion and enantiomeric excess were quantified by GC.

\subsection{Screening the Effect of Substrate Concentration on the Optimal TAs with Ketones $\mathbf{5 7 a - g}$}

All screening reactions were performed at $30^{\circ} \mathrm{C}$ for $24 \mathrm{~h}$ in a $4 \mathrm{~mL}$ screw-cap vial. To the vial, $100 \mu \mathrm{L}$ of starting material stock solution (0.1-1 M 57a-c. $\mathrm{HCl}$ and 1 equiv. $\mathrm{NaOH}$ or $0.1-1 \mathrm{M} 57 \mathrm{~d}, \mathrm{f} .2 \mathrm{HCl}$ and 2 equiv. $\mathrm{NaOH}$ or $0.1-1 \mathrm{M} 57 \mathbf{e}, \mathbf{g}$ ) and $800 \mu \mathrm{L}$ of amine donor stock solution ( $31.25 \mathrm{v} / \mathrm{v} \%$ IPA and $1.25 \mathrm{mM}$ PLP in potassium phosphate buffer (100 mM, $\mathrm{pH} 7.5)$ ) were added, resulting in the following final concentrations: $57 \mathrm{a}(10-100 \mathrm{mM})$, 
IPA $(25 v / v \%)$, PLP $(1 \mathrm{mM})$. The reaction was started by addition of TA stock solution $(100 \mu \mathrm{L}, 20 \mathrm{mg} / \mathrm{mL}$ TA-025, -254, -256 or -260 in potassium phosphate buffer). After 2, 4 and $24 \mathrm{~h}$, samples $(50 \mu \mathrm{L})$ were taken and added to aqueous $\mathrm{NaOH}$ solution $(50 \mu \mathrm{L}, 5 \mathrm{~N})$ and ethyl acetate $(1 \mathrm{~mL})$. This was followed by the complete drying of the aqueous phase with sodium sulfate. The separated organic phase was derivatized with acetic anhydride $(10 \mu \mathrm{L})$, and conversion and enantiomeric excess were quantified via GC.

\subsection{Scaling-Up the Transamination of 57c}

To an $8 \mathrm{~mL}$ screw-cap vial TA $(10 \mathrm{mg}), 500 \mu \mathrm{L}$ of starting material stock solution $(0.5 \mathrm{M}$ 57c. $\mathrm{HCl}$ and 1 equiv. $\mathrm{NaOH})$ and $4500 \mu \mathrm{L}$ of amine donor stock solution (27.78 $v / v \%$ IPA and $1.11 \mathrm{mM}$ PLP in potassium phosphate buffer $(100 \mathrm{mM}, \mathrm{pH} 7.5))$ were added, resulting in the following final concentrations: $57 \mathrm{c}(50 \mathrm{mM})$, IPA $(25 v / v \%), \operatorname{PLP}(1 \mathrm{mM})$. The reaction was checked by sampling and GC (as given is section in 3.4) until the conversion exceeded 95\% (see Figure S2). Then, the corresponding enantiomer of 55c was isolated.

\subsection{Isolation of the Enantiopure Amines (S)-55a-g}

When applicable, $(S)$-amines were isolated from the substrate concentration screening by unifying samples with conversion $>95 \%$ (see Figure 13 and Figures S1-S6). Otherwise, a 5-time scale-up was performed (see Section 3.6). The $\mathrm{pH}$ of the aqueous phase was set to 13 by addition of $37 \% \mathrm{HCl}$ solution, and the excess IPA was removed by vacuum rotary evaporator while the water was also partially evaporated. The aqueous phase was extracted with dichloromethane until the majority of product resided in the organic phase (usually $5 \times 10 \mathrm{~mL}$ ). The combined organic phases were dried on sodium sulfate and concentrated under vacuum to give the desired product $(S)-55 \mathbf{a}-\mathbf{g}$.

(S)-1-Morpholinopropan-2-amine ((S)-55a). Yield: 47\%; TLC $\left(\mathrm{R}_{\mathrm{f}}\right) 0.31$ (DCM:MeOH: $\left.35 \% \mathrm{NH}_{4} \mathrm{OH} 10: 1: 0.1\right) ;[\alpha]_{\mathrm{D}}{ }^{20}=+31.2(\mathrm{c} 1.12, \mathrm{MeOH}) ;{ }^{1} \mathrm{H}$ NMR $\left(300 \mathrm{MHz}, \mathrm{CDCl}_{3}\right) \delta 4.2(\mathrm{~s}$, $2 \mathrm{H}), 3.71(\mathrm{t}, J=4.4 \mathrm{~Hz}, 4 \mathrm{H}), 3.20(\mathrm{ddd}, J=12.2,9.3,6.0 \mathrm{~Hz}, 1 \mathrm{H}), 2.63-2.30(\mathrm{~m}, 4 \mathrm{H}), 2.30(\mathrm{~d}$, $J=4.6 \mathrm{~Hz}, 2 \mathrm{H}), 1.20(\mathrm{~d}, J=6.4 \mathrm{~Hz}, 3 \mathrm{H}) ;{ }^{13} \mathrm{C} \mathrm{NMR}\left(75 \mathrm{MHz}, \mathrm{CDCl}_{3}\right) \delta$ 67.1, 65.2, 54.0, 44.1, 19.3; IR (cm $\left.{ }^{-1}\right)$ : 3349, 2956, 2926, 2908, 2804, 1577, 1458, 1417, 1290, 1120, 1093, 962.

(S)-1-Thiomorpholinopropan-2-amine $((S)-55 b)$. Yield: 74\%; TLC $\left(\mathrm{R}_{\mathrm{f}}\right) 0.30(\mathrm{DCM}: \mathrm{MeOH}$ : $\left.35 \% \mathrm{NH}_{4} \mathrm{OH} 10: 1: 0.1\right) ;[\alpha]_{\mathrm{D}}{ }^{20}=+44.0$ (c 0.64, MeOH); ${ }^{1} \mathrm{H}$ NMR $\left(500 \mathrm{MHz}, \mathrm{CDCl}_{3}\right) \delta$ 3.07-2.98 (m, 1H), 2.83-2.77 (m, 2H), $2.68(\mathrm{dt}, J=12.8,3.4 \mathrm{~Hz}, 2 \mathrm{H}), 2.66-2.60(\mathrm{~m}, 4 \mathrm{H})$, $2.27(\mathrm{dd}, J=12.6,3.7 \mathrm{~Hz}, 1 \mathrm{H}), 2.06(\mathrm{dd}, J=12.6,9.9 \mathrm{~Hz}, 1 \mathrm{H}), 2.01(\mathrm{~s}, 2 \mathrm{H}), 1.01(\mathrm{~d}, J=6.3 \mathrm{~Hz}$, $3 \mathrm{H}) ;{ }^{13} \mathrm{C} \mathrm{NMR}\left(126 \mathrm{MHz}, \mathrm{CDCl}_{3}\right) \delta 67.8,55.7,43.4,28.3,21.2 ; \mathrm{IR}\left(\mathrm{cm}^{-1}\right): 3338,2923,2903$, 2801, 1617, 1567, 1485, 1345, 1277, 1110, 961.

(S)-1-(4-Methylpiperidin-1-yl)propan-2-amine $((S)-55 \mathrm{c})$. Yield: 83\%; TLC $\left(\mathrm{R}_{\mathrm{f}}\right) 0.25$ (DCM:MeOH: 35\% $\left.\mathrm{NH}_{4} \mathrm{OH} 10: 1: 0.1\right) ;[\alpha]_{\mathrm{D}}{ }^{20}=+34.2$ (c 1.20, MeOH); ${ }^{1} \mathrm{H} \mathrm{NMR}(500 \mathrm{MHz}$, $\left.\mathrm{CDCl}_{3}\right) \delta 3.81-3.43(\mathrm{~m}, 4 \mathrm{H}), 3.11-3.00(\mathrm{~m}, 1 \mathrm{H}), 2.97-2.68(\mathrm{~m}, 2 \mathrm{H}), 1.88-1.74(\mathrm{~m}, 2 \mathrm{H})$, $1.71-1.58(\mathrm{~m}, 3 \mathrm{H}), 1.50-1.45(\mathrm{~m}, 2 \mathrm{H}), 1.31-1.18(\mathrm{~m}, 2 \mathrm{H}), 1.03-0.95(\mathrm{~m}, 3 \mathrm{H}), 0.87-0.78(\mathrm{~m}$, 1H); IR (cm $\left.{ }^{-1}\right)$ : 3351, 2949, 2920, 2870, 2802, 2774, 1577, 1454, 1376, 1123, 1083, 980, 817.

(S)-1-(4-Methylpiperazin-1-yl)propan-2-amine ((S)-55d). Yield: 65\%; TLC $\left(\mathrm{R}_{\mathrm{f}}\right) 0.18$ (DCM:MeOH: 35\% $\left.\mathrm{NH}_{4} \mathrm{OH} 10: 1: 0.1\right) ;[\alpha]_{\mathrm{D}}{ }^{20}=+36.6$ (c 1.20, MeOH); ${ }^{1} \mathrm{H}$ NMR (500 MHz, $\left.\mathrm{CDCl}_{3}\right) \delta 3.05-2.94(\mathrm{~m}, 1 \mathrm{H}), 2.59-2.29(\mathrm{~m}, 8 \mathrm{H}), 2.23(\mathrm{~s}, 3 \mathrm{H}), 2.14(\mathrm{dd}, J=12.2,3.9 \mathrm{~Hz}, 1 \mathrm{H})$, $2.08(\mathrm{dd}, J=12.3,9.7 \mathrm{~Hz}, 1 \mathrm{H}), 1.92(\mathrm{~s}, 2 \mathrm{H}), 0.97(\mathrm{~d}, J=6.3 \mathrm{~Hz}, 3 \mathrm{H}) ;{ }^{13} \mathrm{C} \mathrm{NMR}(126 \mathrm{MHz}$, $\left.\mathrm{CDCl}_{3}\right) \delta 67.2,55.4,46.1,43.3,21.4 ; \mathrm{IR}\left(\mathrm{cm}^{-1}\right): 3357,2935,2792,1585,1456,1373,1294,1282$, $1165,1013,816$.

tert-Butyl (S)-4-(2-aminopropyl)piperazine-1-carboxylate $((S)-55 e)$. Yield: 59\%; TLC $\left(\mathrm{R}_{\mathrm{f}}\right)$ 0.25 (DCM:MeOH: 35\% NH ${ }_{4} \mathrm{OH}$ 10:1:0.1); $[\alpha]_{\mathrm{D}}{ }^{20}=+29.4$ (c 1.20, $\left.\mathrm{MeOH}\right) ;{ }^{1} \mathrm{H} \mathrm{NMR}(500 \mathrm{MHz}$, $\left.\mathrm{CDCl}_{3}\right)$ 反 3.44-3.27 (m, 4H), 3.07-2.97 (m, 1H), $2.44(\mathrm{dt}, J=10.7,5.0 \mathrm{~Hz}, 2 \mathrm{H}), 2.28-2.20(\mathrm{~m}$, 2H), $2.15(\mathrm{dd}, J=12.3,4.1 \mathrm{~Hz}, 1 \mathrm{H}), 2.10(\mathrm{dd}, J=12.3,9.5 \mathrm{~Hz}, 1 \mathrm{H}), 1.98(\mathrm{~s}, 2 \mathrm{H}), 1.41(\mathrm{~s}, 9 \mathrm{H})$, $0.99(\mathrm{~d}, J=6.3 \mathrm{~Hz}, 3 \mathrm{H}) ;{ }^{13} \mathrm{C}$ NMR $\left(126 \mathrm{MHz}, \mathrm{CDCl}_{3}\right) \delta$ 154.8, 79.6, 67.0, 43.4, 28.5, 21.2; IR $\left(\mathrm{cm}^{-1}\right)$ : 3368, 2970, 2931, 2864, 2810, 1692, 1457, 1420, 1365, 1247, 1170, 1124, 1006.

(S)-1-(4-Phenylpiperazin-1-yl)propan-2-amine ((S)-55f). Yield: 81\%; TLC $\left(\mathrm{R}_{\mathrm{f}}\right) 0.28$ (DCM:MeOH: 35\% $\mathrm{NH}_{4} \mathrm{OH}$ 10:1:0.1); $[\alpha]_{\mathrm{D}}{ }^{20}=+36.0$ (c 1.20, $\left.\mathrm{MeOH}\right) ;{ }^{1} \mathrm{H} \mathrm{NMR}(500 \mathrm{MHz}$, 
$\left.\mathrm{CDCl}_{3}\right) \delta 7.30-7.22(\mathrm{~m}, 2 \mathrm{H}), 6.96-6.88(\mathrm{~m}, 2 \mathrm{H}), 6.85(\mathrm{t}, J=7.3 \mathrm{~Hz}, 1 \mathrm{H}), 3.27-3.13(\mathrm{~m}, 4 \mathrm{H})$, 3.16-3.05 (m, 1H), $2.71(\mathrm{ddd}, J=10.6,6.7,3.5 \mathrm{~Hz}, 2 \mathrm{H}), 2.51(\mathrm{ddd}, J=10.8,6.5,3.5 \mathrm{~Hz}, 2 \mathrm{H})$, 2.30-2.14 (m, 2H), $1.90(\mathrm{~s}, 2 \mathrm{H}), 1.06(\mathrm{dd}, J=6.3,1.3 \mathrm{~Hz}, 3 \mathrm{H}) ;{ }^{13} \mathrm{C} \mathrm{NMR}\left(126 \mathrm{MHz} \mathrm{CDCl}_{3}\right) \delta$ 151.5, 129.2, 119.7, 116.1, 67.2, 53.7, 49.4, 43.5, 21.4; IR (cm $\left.{ }^{-1}\right)$ : 3339, 2951, 2821, 1599, 1502, $1453,1443,1305,1234,1145,1011,917,752$.

(S)-1-(4-Benzylpiperazin-1-yl)propan-2-amine $((S)-55 g)$. Yield: 94\%; TLC $\left(\mathrm{R}_{\mathrm{f}}\right) 0.22$ (DCM:MeOH: 35\% $\mathrm{NH}_{4} \mathrm{OH}$ 10:1:0.1); $[\alpha]_{\mathrm{D}}{ }^{20}=+26.9$ (c 1.20, $\left.\mathrm{MeOH}\right) ;{ }^{1} \mathrm{H}$ NMR (500 MHz, $\left.\mathrm{CDCl}_{3}\right) \delta 7.35-7.21(\mathrm{~m}, 5 \mathrm{H}), 3.50(\mathrm{~s}, 2 \mathrm{H}), 3.07(\mathrm{dtd}, J=13.1,6.7,3.6 \mathrm{~Hz}, 1 \mathrm{H}), 2.67-2.31(\mathrm{~m}$, 12H), 2.26-2.12 (m, 2H), $1.06(\mathrm{~d}, \mathrm{~J}=4.7 \mathrm{~Hz}, 3 \mathrm{H}) ;{ }^{13} \mathrm{C} \mathrm{NMR}\left(126 \mathrm{MHz}, \mathrm{CDCl}_{3}\right) \delta 138.8,129.3$, 128.3, 127.2, 70.7, 63.2, 53.3, 43.7, 20.9; IR ( $\left.\mathrm{cm}^{-1}\right)$ : 3360, 2936, 1807, 1671, 1585, 1453, 1297, $1155,1138,1010,827,737,697$.

\section{Conclusions}

The transaminase-catalyzed asymmetric transamination of ketones comprising heterocyclic 3D rings $(\mathbf{5 7} \mathbf{a}-\mathbf{g})$ under mild conditions proved to be an excellent alternative to "traditional" chemical methods for synthesis of chiral amines 55a-g representing a new class of potential drug scaffolds. Using morpholine-containing ketone 57a as model compound, high-performing TAs were selected from the Codex ${ }^{\circledR}$ Amine Transaminase Screening Kit. Screening substrate concentration and amine donor equivalent enabled raising the substrate concentration up to $17.8 \mathrm{mg} / \mathrm{mL}$ of $57 \mathrm{a}$. The optimized conditions for the transamination were applicable to convert further heterocyclic substrates $57 \mathbf{b}-\mathrm{g}$ to enantiopure amines $(R)-\mathbf{5 5 a}-\mathbf{g}$ or $(S)-55 \mathbf{a}-\mathbf{g}$. The asymmetric transamination leading to the $(S)$-enantiomers $(S)$-55a-g at larger scale enabled characterization of these products.

The reported route allowed the preparation of the desired enantiopure amines in two $(55 a-d, f)$, or three $(55 e, g)$ steps starting from the corresponding commercially available saturated amine heterocycles (56a-g). These new enantiopure amines $(R)-55 a-g$ or $(S)$ 55a-g can serve as building blocks for the preparation of chiral APIs containing the 3D heterocyclic scaffolds as chiral sidechains with substitution $\left(S_{1}\right)$ on the primary amine moiety or even as chiral backbones with double functionalization $\left(S_{1}\right.$ and $\left.S_{2}\right)$ on two ends (Figure 15).

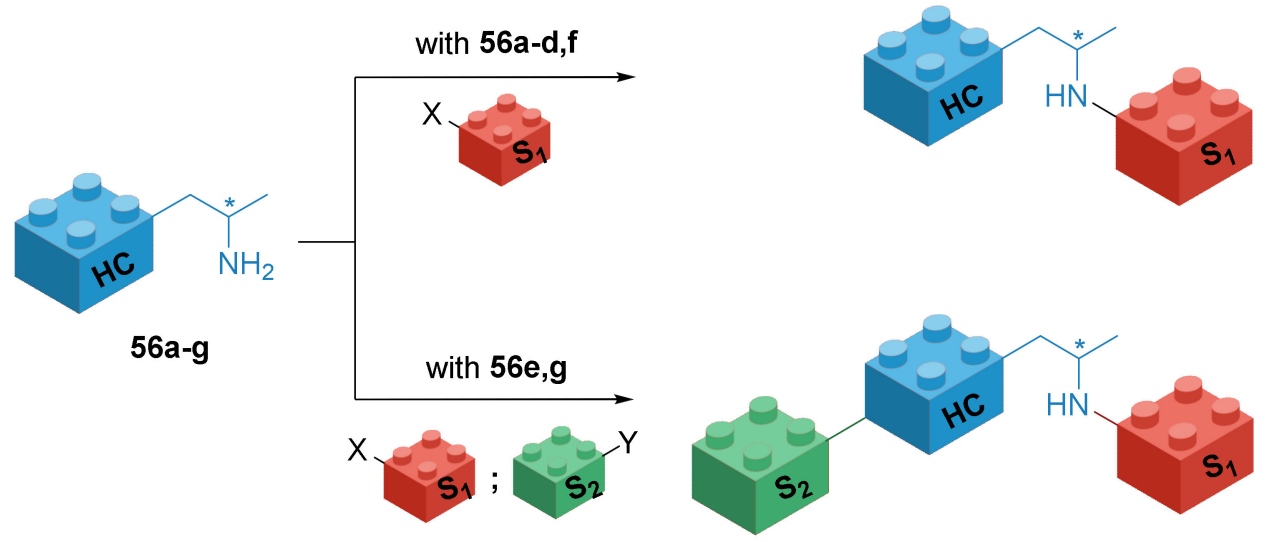

Figure 15. Applicability of potential drug scaffold chiral amines $[(S)$ - or $(R)-55 a-g]$ with 3D heterocyclic units (HC) as building blocks for the preparation of enantiopure APIs.

Supplementary Materials: The following are available online at https: / www.mdpi.com/article/ 10.3390/catal11121501/s1, Table S1: GC methods and retention times for the conversion value determination by chiral GC analysis, Table S2: Varying IPA content based on substrate concentration. Figures S1-S6: Substrate concentration study of 57b-g. Figure S7: ${ }^{1} \mathrm{H}$ NMR spectra of $(S)-55 c$ (a) without TFA, with (b) 10\% TFA, (c) 50\% TFA. Figures S8-S35: GC chromatograms of 57a-g, $(S)-55 a-g,(R)-55 a-g$ and mixtures of the enantiomers. Figures S36-S53: ${ }^{1} \mathrm{H}-$ and ${ }^{13} \mathrm{C}-\mathrm{NMR}$ of $57 \mathbf{e}-\mathrm{g}$ and $(S)-55 a-g$. 
Author Contributions: Conceptualization, Á.M.-L. and L.P.; investigation, Á.M.-L. and F.Z.; writingoriginal draft preparation, Á.M.-L.; writing-review and editing, L.P.; supervision, R.M. and L.P. All authors have read and agreed to the published version of the manuscript.

Funding: Á.M.-L. thanks the fellowship (SPAC/BDE/08) from Hovione Farmaciência. This work was supported by the Higher Education Excellence Program of the Ministry of Human Capacities (Budapest, Hungary) in the frame of the biotechnology research area of Budapest University of Technology and Economics (TKP2020 IES, Grant No. BME-IE-BIO). L.P. thanks for the support from the National Research, Development and Innovation Office (Budapest, Hungary; SNN-125637).

Data Availability Statement: Further data are available on request from the corresponding authors.

Conflicts of Interest: The authors declare no conflict of interest.

\section{References}

1. Lipinski, C.A.; Lombardo, F.; Dominy, B.W.; Feeney, P.J. Experimental and Computational Approaches to Estimate Solubility and Permeability in Drug Discovery and Development Settings. Adv. Drug Deliv. Rev. 1997, 23, 3-25. [CrossRef]

2. Lipinski, C.A. Lead- and Drug-like Compounds: The Rule-of-Five Revolution. Drug Discov. Today Technol. $2004,1,337-341$. [CrossRef]

3. Ritchie, T.J.; Macdonald, S.J.F. The Impact of Aromatic Ring Count on Compound Developability-Are Too Many Aromatic Rings a Liability in Drug Design? Drug Discov. Today 2009, 14, 1011-1020. [CrossRef] [PubMed]

4. Galloway, W.R.J.D.; Isidro-Llobet, A.; Spring, D.R. Diversity-Oriented Synthesis as a Tool for the Discovery of Novel Biologically Active Small Molecules. Nat. Commun. 2010, 1, 80. [CrossRef]

5. Aldeghi, M.; Malhotra, S.; Selwood, D.L.; Chan, A.W.E. Two- and Three-dimensional Rings in Drugs. Chem. Biol. Drug Des. 2014, 83, 450-461. [CrossRef]

6. Lovering, F.; Bikker, J.; Humblet, C. Escape from Flatland: Increasing Saturation as an Approach to Improving Clinical Success. J. Med. Chem. 2009, 52, 6752-6756. [CrossRef] [PubMed]

7. Ritchie, T.J.; MacDonald, S.J.F.; Young, R.J.; Pickett, S.D. The Impact of Aromatic Ring Count on Compound Developability: Further Insights by Examining Carbo- and Hetero-Aromatic and -Aliphatic Ring Types. Drug Discov. Today 2011, 16, 164-171. [CrossRef]

8. Vitaku, E.; Smith, D.T.; Njardarson, J.T. Analysis of the Structural Diversity, Substitution Patterns, and Frequency of Nitrogen Heterocycles among U.S. FDA Approved Pharmaceuticals. J. Med. Chem. 2014, 57, 10257-10274. [CrossRef]

9. Vardanyan, R. Piperidine-Based Drug Discovery, 1st ed.; Elsevier Ltd.: Amsterdam, The Netherlands, 2017; ISBN 978-0-12-805157-3.

10. Shaquiquzzaman, M.; Verma, G.; Marella, A.; Akhter, M.; Akhtar, W.; Khan, M.F.; Tasneem, S.; Alam, M.M. Piperazine Scaffold: A Remarkable Tool in Generation of Diverse Pharmacological Agents. Eur. J. Med. Chem. 2015, 102, 487-529. [CrossRef] [PubMed]

11. Kourounakis, A.P.; Xanthopoulos, D.; Tzara, A. Morpholine as a Privileged Structure: A Review on the Medicinal Chemistry and Pharmacological Activity of Morpholine Containing Bioactive Molecules. Med. Res. Rev. 2020, 40, 709-752. [CrossRef] [PubMed]

12. Caron, S. Practical Synthetic Organic Chemistry, 2nd ed.; John Wiley \& Sons Inc.: Hoboken, NJ, USA, $2020 ;$ ISBN 9781119448853.

13. Savile, C.K.; Janey, J.M.; Mundorff, E.C.; Moore, J.C.; Tam, S.; Jarvis, W.R.; Colbeck, J.C.; Krebber, A.; Fleitz, F.J.; Brands, J.; et al. Biocatalytic Asymmetric Synthesis of Chiral Amines from Ketones Applied to Sitagliptin Manufacture. Science 2010, 329, 305-309. [CrossRef] [PubMed]

14. Kelly, S.A.; Pohle, S.; Wharry, S.; Mix, S.; Allen, C.C.R.; Moody, T.S.; Gilmore, B.F. Application of $\omega$-Transaminases in the Pharmaceutical Industry. Chem. Rev. 2018, 118, 349-367. [CrossRef]

15. Ghislieri, D.; Turner, N.J. Biocatalytic Approaches to the Synthesis of Enantiomerically Pure Chiral Amines. Top. Catal. 2014, 57, 284-300. [CrossRef]

16. Frodsham, L.; Golden, M.; Hard, S.; Kenworthy, M.N.; Klauber, D.J.; Leslie, K.; Macleod, C.; Meadows, R.E.; Mulholland, K.R.; Reilly, J.; et al. Use of $\omega$-Transaminase Enzyme Chemistry in the Synthesis of a JAK2 Kinase Inhibitor. Org. Process Res. Dev. 2013, 17, 1123-1130. [CrossRef]

17. Meadows, R.E.; Mulholland, K.R.; Schürmann, M.; Golden, M.; Kierkels, H.; Meulenbroeks, E.; Mink, D.; May, O.; Squire, C.; Straatman, H.; et al. Efficient Synthesis of (S)-1-(5-Fluoropyrimidin-2-Yl)Ethylamine Using an $\omega$-Transaminase Biocatalyst in a Two-Phase System. Org. Process Res. Dev. 2013, 17, 1117-1122. [CrossRef]

18. Molinaro, C.; Bulger, P.G.; Lee, E.E.; Kosjek, B.; Lau, S.; Gauvreau, D.; Howard, M.E.; Wallace, D.J.; O'Shea, P.D. CRTH2 Antagonist MK-7246: A Synthetic Evolution from Discovery through Development. J. Org. Chem. 2012, 77, 2299-2309. [CrossRef]

19. Peng, Z.; Wong, J.W.; Hansen, E.C.; Puchlopek-Dermenci, A.L.A.; Clarke, H.J. Development of a Concise, Asymmetric Synthesis of a Smoothened Receptor (Smo) Inhibitor: Enzymatic Transamination of a 4-Piperidinone with Dynamic Kinetic Resolution. Org. Lett. 2014, 16, 860-863. [CrossRef] [PubMed]

20. Mangion, I.K.; Sherry, B.D.; Yin, J.; Fleitz, F.J. Enantioselective Synthesis of a Dual Orexin Receptor Antagonist. Org. Lett. 2012, 14, 3458-3461. [CrossRef] 
21. Chung, C.K.; Bulger, P.G.; Kosjek, B.; Belyk, K.M.; Rivera, N.; Scott, M.E.; Humphrey, G.R.; Limanto, J.; Bachert, D.C.; Emerson, K.M. Process Development of C-N Cross-Coupling and Enantioselective Biocatalytic Reactions for the Asymmetric Synthesis of Niraparib. Org. Process Res. Dev. 2014, 18, 215-227. [CrossRef]

22. Girardin, M.; Ouellet, S.G.; Gauvreau, D.; Moore, J.C.; Hughes, G.; Devine, P.N.; O'Shea, P.D.; Campeau, L.-C. Convergent Kilogram-Scale Synthesis of Dual Orexin Receptor Antagonist. Org. Process Res. Dev. 2013, 17, 61-68. [CrossRef]

23. Chung, J.Y.L.; Zhong, Y.-L.; Maloney, K.M.; Reamer, R.A.; Moore, J.C.; Strotman, H.; Kalinin, A.; Feng, R.; Strotman, N.A.; Xiang, B.; et al. Unusual Pyrimidine Participation: Efficient Stereoselective Synthesis of Potent Dual Orexin Receptor Antagonist MK-6096. Org. Lett. 2014, 16, 5890-5893. [CrossRef]

24. Chung, J.Y.L.; Marcune, B.; Strotman, H.R.; Petrova, R.I.; Moore, J.C.; Dormer, P.G. Synthesis of ((3 R, 6 R)-6-Methylpiperidin3-Yl)Methanol via Biocatalytic Transamination and Crystallization-Induced Dynamic Resolution. Org. Process Res. Dev. 2015, 19, 1418-1423. [CrossRef]

25. Dunbabin, A.; Subrizi, F.; Ward, J.M.; Sheppard, T.D.; Hailes, H.C. Furfurylamines from Biomass: Transaminase Catalysed Upgrading of Furfurals. Green Chem. 2017, 19, 397-404. [CrossRef]

26. Paul, C.E.; Rodríguez-Mata, M.; Busto, E.; Lavandera, I.; Gotor-Fernández, V.; Gotor, V.; García-Cerrada, S.; Mendiola, J.; de Frutos, Ó.; Collado, I. Transaminases Applied to the Synthesis of High Added-Value Enantiopure Amines. Org. Process Res. Dev. 2014, 18, 788-792. [CrossRef]

27. López-Iglesias, M.; González-Martínez, D.; Gotor, V.; Busto, E.; Kroutil, W.; Gotor-Fernández, V. Biocatalytic Transamination for the Asymmetric Synthesis of Pyridylalkylamines. Structural and Activity Features in the Reactivity of Transaminases. ACS Catal. 2016, 6, 4003-4009. [CrossRef]

28. Galman, J.L.; Slabu, I.; Weise, N.J.; Iglesias, C.; Parmeggiani, F.; Lloyd, R.C.; Turner, N.J. Biocatalytic Transamination with Near-Stoichiometric Inexpensive Amine Donors Mediated by Bifunctional Mono- and Di-Amine Transaminases. Green Chem. 2017, 19, 361-366. [CrossRef]

29. Martínez-Montero, L.; Gotor, V.; Gotor-Fernández, V.; Lavandera, I. Stereoselective Amination of Racemic Sec-Alcohols through Sequential Application of Laccases and Transaminases. Green Chem. 2017, 19, 474-480. [CrossRef]

30. Martínez-Montero, L.; Gotor, V.; Gotor-Fernández, V.; Lavandera, I. But-2-Ene-1,4-Diamine and But-2-Ene-1,4-Diol as Donors for Thermodynamically Favored Transaminase- and Alcohol Dehydrogenase-Catalyzed Processes. Adv. Synth. Catal. 2016, 358, 1618-1624. [CrossRef]

31. Dawood, A.W.H.; de Souza, R.O.M.A.; Bornscheuer, U.T. Asymmetric Synthesis of Chiral Halogenated Amines Using Amine Transaminases. ChemCatChem 2018, 10, 951-955. [CrossRef]

32. Holzer, A.K.; Hiebler, K.; Mutti, F.G.; Simon, R.C.; Lauterbach, L.; Lenz, O.; Kroutil, W. Asymmetric Biocatalytic Amination of Ketones at the Expense of NH 3 and Molecular Hydrogen. Org. Lett. 2015, 17, 2431-2433. [CrossRef]

33. López-Iglesias, M.; González-Martínez, D.; Rodríguez-Mata, M.; Gotor, V.; Busto, E.; Kroutil, W.; Gotor-Fernández, V. Asymmetric Biocatalytic Synthesis of Fluorinated Pyridines through Transesterification or Transamination: Computational Insights into the Reactivity of Transaminases. Adv. Synth. Catal. 2017, 359, 279-291. [CrossRef]

34. Mourelle-Insua, Á.; López-Iglesias, M.; Gotor, V.; Gotor-Fernández, V. Stereoselective Access to 1-[2-Bromo(Het)Aryloxy]Propan2-Amines Using Transaminases and Lipases; Development of a Chemoenzymatic Strategy Toward a Levofloxacin Precursor. J. Org. Chem. 2016, 81, 9765-9774. [CrossRef]

35. Fischereder, E.-M.M.; Pressnitz, D.; Kroutil, W. Stereoselective Cascade to C3-Methylated Strictosidine Derivatives Employing Transaminases and Strictosidine Synthases. ACS Catal. 2016, 6, 23-30. [CrossRef]

36. Monti, D.; Forchin, M.C.; Crotti, M.; Parmeggiani, F.; Gatti, F.G.; Brenna, E.; Riva, S. Cascade Coupling of Ene-Reductases and $\omega$-Transaminases for the Stereoselective Synthesis of Diastereomerically Enriched Amines. ChemCatChem 2015, 7, 3106-3109. [CrossRef]

37. Höhne, M.; Kühl, S.; Robins, K.; Bornscheuer, U.T. Efficient Asymmetric Synthesis of Chiral Amines by Combining Transaminase and Pyruvate Decarboxylase. ChemBioChem 2008, 9, 363-365. [CrossRef] [PubMed]

38. Hegarty, E.; Paradisi, F. Implementation of Biocatalysis in Continuous Flow for the Synthesis of Small Cyclic Amines. Chimia 2020, 74, 890-894. [CrossRef] [PubMed]

39. Feng, Y.; Luo, Z.; Sun, G.; Chen, M.; Lai, J.; Lin, W.; Goldmann, S.; Zhang, L.; Wang, Z. Development of an Efficient and Scalable Biocatalytic Route to (3R)-3-Aminoazepane: A Pharmaceutically Important Intermediate. Org. Process Res. Dev. 2017, 21, 648-654. [CrossRef]

40. Lerchner, A.; Achatz, S.; Rausch, C.; Haas, T.; Skerra, A. Coupled Enzymatic Alcohol-to-Amine Conversion of Isosorbide Using Engineered Transaminases and Dehydrogenases. ChemCatChem 2013, 5, 3374-3383. [CrossRef]

41. Weiß, M.S.; Pavlidis, I.V.; Spurr, P.; Hanlon, S.P.; Wirz, B.; Iding, H.; Bornscheuer, U.T. Protein-Engineering of an Amine Transaminase for the Stereoselective Synthesis of a Pharmaceutically Relevant Bicyclic Amine. Org. Biomol. Chem. 2016, 14, 10249-10254. [CrossRef]

42. Pressnitz, D.; Fuchs, C.S.; Sattler, J.H.; Knaus, T.; Macheroux, P.; Mutti, F.G.; Kroutil, W. Asymmetric Amination of Tetralone and Chromanone Derivatives Employing $\omega$-Transaminases. ACS Catal. 2013, 3, 555-559. [CrossRef]

43. Truppo, M.D.; Rozzell, J.D.; Turner, N.J. Efficient Production of Enantiomerically Pure Chiral Amine at Conc 50 g/L Using Transaminase. Org. Process Res. Dev. 2010, 14, 234-237. [CrossRef] 
44. Ryan, J.; Šiaučiulis, M.; Gomm, A.; Maciá, B.; O’Reilly, E.; Caprio, V. Transaminase Triggered Aza-Michael Approach for the Enantioselective Synthesis of Piperidine Scaffolds. J. Am. Chem. Soc. 2016, 138, 15798-15800. [CrossRef] [PubMed]

45. Taday, F.; Ryan, J.; Argent, S.P.; Caprio, V.; Maciá, B.; O’Reilly, E. Asymmetric Construction of Alkaloids by Employing a Key $\omega$-Transaminase Cascade. Chem. A Eur. J. 2020, 26, 3729-3732. [CrossRef] [PubMed]

46. Simon, R.C.; Grischek, B.; Zepeck, F.; Steinreiber, A.; Belaj, F.; Kroutil, W. Regio- and Stereoselective Monoamination of Diketones without Protecting Groups. Angew. Chemie Int. Ed. 2012, 51, 6713-6716. [CrossRef] [PubMed]

47. Simon, R.C.; Zepeck, F.; Kroutil, W. Chemoenzymatic Synthesis of All Four Diastereomers of 2,6-Disubstituted Piperidines through Stereoselective Monoamination of 1,5-Diketones. Chem. A Eur. J. 2013, 19, 2859-2865. [CrossRef]

48. Simon, R.C.; Fuchs, C.S.; Lechner, H.; Zepeck, F.; Kroutil, W. Concise Chemoenzymatic Three-Step Total Synthesis of Isosolenopsin through Medium Engineering. Eur. J. Org. Chem. 2013, 2013, 3397-3402. [CrossRef] [PubMed]

49. France, S.P.; Hussain, S.; Hill, A.M.; Hepworth, L.J.; Howard, R.M.; Mulholland, K.R.; Flitsch, S.L.; Turner, N.J. One-Pot Cascade Synthesis of Mono- and Disubstituted Piperidines and Pyrrolidines Using Carboxylic Acid Reductase (CAR), $\omega$-Transaminase ( $\omega$-TA), and Imine Reductase (IRED) Biocatalysts. ACS Catal. 2016, 6, 3753-3759. [CrossRef]

50. O’Reilly, E.; Iglesias, C.; Ghislieri, D.; Hopwood, J.; Galman, J.L.; Lloyd, R.C.; Turner, N.J. A Regio- and Stereoselective $\omega$ Transaminase/Monoamine Oxidase Cascade for the Synthesis of Chiral 2,5-Disubstituted Pyrrolidines. Angew. Chemie Int. Ed. 2014, 53, 2447-2450. [CrossRef] [PubMed]

51. Hepworth, L.J.; France, S.P.; Hussain, S.; Both, P.; Turner, N.J.; Flitsch, S.L. Enzyme Cascades in Whole Cells for the Synthesis of Chiral Cyclic Amines. ACS Catal. 2017, 7, 2920-2925. [CrossRef]

52. Brotherton-Pleiss, C.E.; Dillon, M.P.; Ford, A.P.D.W.; Gever, J.R.; Carter, D.S.; Gleason, S.K.; Lin, C.J.; Moore, A.G.; Thompson, A.W.; Villa, M.; et al. Discovery and Optimization of RO-85, a Novel Drug-like, Potent, and Selective P2X3 Receptor Antagonist. Bioorganic Med. Chem. Lett. 2010, 20, 1031-1036. [CrossRef] [PubMed]

53. Glatthar, R.; Stojanovic, A.; Troxler, T.; Mattes, H.; Möbitz, H.; Beerli, R.; Blanz, J.; Gassmann, E.; Drückes, P.; Fendrich, G.; et al. Discovery of Imidazoquinolines as a Novel Class of Potent, Selective, and in Vivo Efficacious Cancer Osaka Thyroid (COT) Kinase Inhibitors. J. Med. Chem. 2016, 59, 7544-7560. [CrossRef] [PubMed]

54. Hansen, M.M.; Kallman, N.J.; Koenig, T.M.; Linder, R.J.; Richey, R.N.; Rizzo, J.R.; Ward, J.A.; Yu, H.; Zhang, T.Y.; Mitchell, D. Double Heck Route to a Dibenzoxepine and Convergent Suzuki Cross-Coupling Strategy for the Synthesis of an MR Antagonist. Org. Process Res. Dev. 2017, 21, 208-217. [CrossRef]

55. Kondaparla, S.; Soni, A.; Manhas, A.; Srivastava, K.; Puri, S.K.; Katti, S.B. Synthesis and Antimalarial Activity of New 4Aminoquinolines Active against Drug Resistant Strains. RSC Adv. 2016, 6, 105676-105689. [CrossRef]

56. Dola, V.R.; Soni, A.; Agarwal, P.; Ahmad, H.; Raju, K.S.R.; Rashid, M.; Wahajuddin, M.; Srivastava, K.; Haq, W.; Dwivedi, A.K.; et al. Synthesis and Evaluation of Chirally Defined Side Chain Variants of 7-Chloro-4-Aminoquinoline To Overcome Drug Resistance in Malaria Chemotherapy. Antimicrob. Agents Chemother. 2017, 61, e01152-16. [CrossRef]

57. Beck, H.P.; Kohn, T.; Rubenstein, S.; Hedberg, C.; Schwandner, R.; Hasslinger, K.; Dai, K.; Li, C.; Liang, L.; Wesche, H.; et al. Discovery of Potent LPA2 (EDG4) Antagonists as Potential Anticancer Agents. Bioorganic Med. Chem. Lett. 2008, 18, $1037-1041$. [CrossRef]

58. Abou-Gharbia, M.A.; Childers, W.E.; Fletcher, H.; McGaughey, G.; Patel, U.; Webb, M.B.; Yardley, J.; Andree, T.; Boast, C.; Kucharik, R.J.; et al. Synthesis and SAR of Adatanserin: Novel Adamantyl Aryl- and Heteroarylpiperazines with Dual Serotonin 5-HT(1A) and 5-HT2 Activity as Potential Anxiolytic and Antidepressant Agents. J. Med. Chem. 1999, 42, 5077-5094. [CrossRef]

59. Li, F.F.; Stubbing, L.A.; Kavianinia, I.; Abbattista, M.R.; Harris, P.W.R.; Smaill, J.B.; Patterson, A.V.; Brimble, M.A. Synthesis and Antiproliferative Activity of C- and N-Terminal Analogues of Culicinin D. Bioorganic Med. Chem. Lett. 2020, 30, 127331. [CrossRef] [PubMed]

60. Wang, B.; Land, H.; Berglund, P. An Efficient Single-Enzymatic Cascade for Asymmetric Synthesis of Chiral Amines Catalyzed by $\omega$-Transaminase. Chem. Commun. 2013, 49, 161-163. [CrossRef] [PubMed]

61. Mourelle-Insua, Á.; Zampieri, L.A.; Lavandera, I.; Gotor-Fernández, V. Conversion of $\gamma$ - and $\delta$-Keto Esters into Optically Active Lactams. Transaminases in Cascade Processes. Adv. Synth. Catal. 2018, 360, 686-695. [CrossRef]

62. Koszelewski, D.; Lavandera, I.; Clay, D.; Rozzell, D.; Kroutil, W. Asymmetric Synthesis of Optically Pure Pharmacologically Relevant Amines Employing w-Transaminases. Adv. Synth. Catal. 2008, 350, 2761-2766. [CrossRef]

63. Hanwell, M.D.; Curtis, D.E.; Lonie, D.C.; Vandermeersch, T.; Zurek, E.; Hutchison, G.R. Avogadro: An Advanced Semantic Chemical Editor, Visualization, and Analysis Platform. J. Cheminform. 2012, 4, 1-17. [CrossRef] [PubMed]

64. Lakó, Á.; Poppe, L.; Mendonça, R. Efficient Synthesis of Pharmaceutically Relevant Prochiral Heterocyclic Aminoketones. Period. Polytech. Chem. Eng. 2021, 65, 177-182. [CrossRef] 